\section{Fabio Lopes de Souza Santos}

Arquiteto, professor doutor do Departamento de Arquitetura e Urbanismo da Escola de Engenharia de São Carlos, Rua Peixoto Gomide, 1956, CEP 01409-002, São Paulo, SP, (11) 3088-5984, sotosantos@uol.com.br.

\section{Resumo}

O artigo discute, dentro da produção dos anos 1960, convergências entre atitudes emergentes nas artes plásticas, arquitetura e design, analisando as produções de Robert Venturi, Roy Lichtenstein, Andy Warhol e Lygia Clark, arte e arquitetura britânicas, arte cinética, design e a concepção de "obra aberta" de Umberto Eco. A análise enfoca a relação entre obra e público proposta por estas produções, a "percepção aberta". O texto situa as inovações nestas produções em meio às mudanças que então se processavam, problematizando como elas abalaram pontos fundamentais do modernismo, especialmente a relação entre movimento moderno e indústria cultural.

Palavras-chave: arte, arquitetura, modernismo. viajante que buscasse em Filadélfia a famosa "Guild House", projeto do escritório de Robert Venturi, deparar-se-ia com um problema inusitado: como reconhecê-la em meio às demais edificações? Ao contrário da produção arquitetônica usual dos anos 1960, ela mal se distingue dos demais prédios daquela típica vizinhança americana. Respeitosa com o regulamento municipal, esta residência para a terceira idade atém-se aos seis andares regulamentares do bairro e segue obediente ao onipresente esquema de fachada e fundos. Nos detalhes e no todo, o arquiteto restringiu-se criteriosamente ao emprego de materiais de fabricação estandardizada e de elementos convencionais: as paredes de tijolos escuros são recortadas por janelas brancas, lembrando as casas ou apartamentos eduardinos. Como apontou o próprio arquiteto, um vaso de flores na janela não tornaria o projeto ridículo. Coroando o conjunto, uma imensa antena de TV dourada arremata a fachada central, a modo de estátua alegórica.

Diante desse mimetismo, o visitante perguntarse-ia se seria realmente o caso de classificar a
"Guild House" como "arquitetura" e surpreenderse-ia ainda mais com a celeuma causada por um edifício de aparência tão "feia e vulgar". Mas um segundo olhar, mais atento e devidamente informado, perceberia uma dupla face neste projeto. A polêmica gerada explica-se pelo prazer com que Venturi cuidadosamente se entregou à criação de situações ambíguas, em um jogo erudito, digno de um maneirista, empregando elementos "vernaculares".

A percepção da fachada central oscila entre configurar uma imensa "Juke-box" feita de tijolos ou o "aggiornamento" da ordem colossal paladiana. O tom irônico é reforçado pela desavergonhada incorporação do letreiro na composição frontal e pela réplica do truque comercial de aplicar materiais nobres apenas na entrada social. A posição inusitada e o heroísmo estrutural da coluna central contrastam com o tom coloquial da fachada. O arco superior é estruturalmente falso, mas revela o espaço de convivência comum. A seqüência de seis andares mimetiza, graças aos apliques, o esquema 


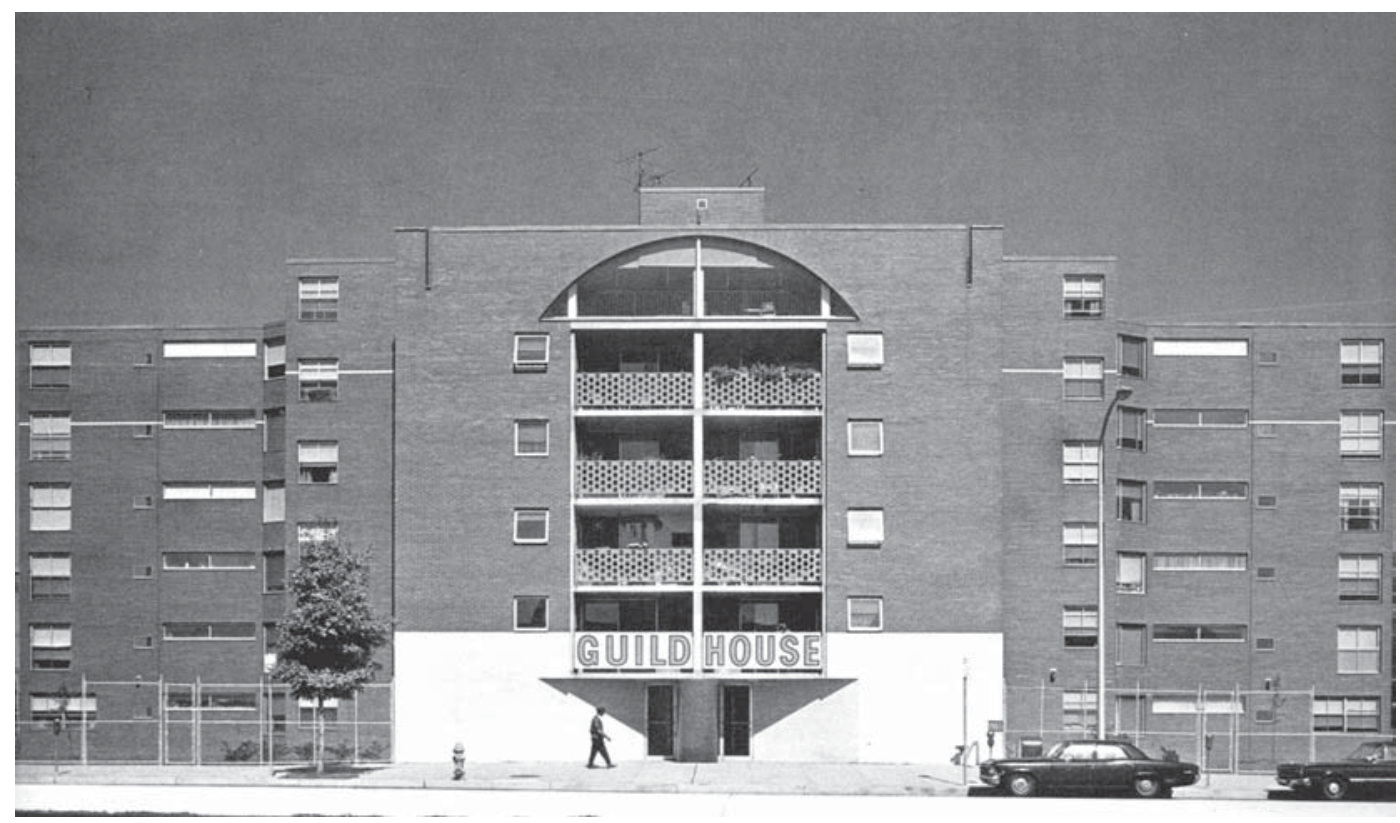

Figura 1: R. Venturi \& Rauch, Cope e Lippincott, a. a. "Guild House", Filadélfia, 1960-63. de base, coluna e frontão e sua parede estende-se lateralmente para simular imponência.

O mesmo jogo ilusionista se reflete na escala enganadora do tamanho das janelas: as mais próximas da rua são pequenas, as mais distantes, grandes, em uma inversão das expectativas geradas pela perspectiva, mudanças de escala que servem também para conferir tensão à fachada. Mesmo a antena pode ser lida como escultura abstrata ou como índice das atividades dos velhos residentes.

Diante das associações despertadas, o visitante conclui que a "Guild House" admite leituras opostas, não apenas enviando mensagens compreensíveis ao "homem-da-rua", inserindo-se como uma mão numa luva no ambiente urbano corriqueiro, mas também fazendo questão de piscar um olho para o público culto.

Em Complexidade e Contradição na Arquitetura, de 1966, Venturi ofereceu indicações que ajudariam a desvendar a perplexidade inicial do observador. Esse livro marcou um hiato na discussão arquitetônica ao atacar as premissas do Movimento Moderno: nele, o autor apresentava positivamente exemplos de edificações renascentistas, maneiristas e barrocas em que a coerência estilística (pregada pelos modernos) era desrespeitada, resultando, entretanto, em uma arquitetura de alta qualidade. A "bête-noir" de seu ataque foi a depurada arquitetura de Mies van der Rohe. Invertendo seu slogan, proclamou que "Less is Bore". Defendia, em suma, a polissemia do signo arquitetônico. Paralelamente denunciava a busca de claridade formal que levara ao esquecimento do caráter simbólico inerente à arquitetura.

A crítica de Venturi estendia-se à incapacidade do urbanismo dos CIAMs de lidar com a estrutura urbana existente. De acordo com o arquiteto, o aspecto exterior do edifício não deveria apenas refletir o espaço interno, mas poderia extrair significado de sua inserção urbana. Venturi concluía defendendo a inclusão do vernacular, se não no projeto, ao menos como presença no espaço urbano. Seu livro foi uma proclamação em favor de uma arquitetura focada no "aqui e agora", contra a sensibilidade moderna excludente e propondo outra, inclusiva. O significado da forma arquitetônica foi declarado não-autônomo; não seria somente resultado do processo de produção e uso, mas estaria conectado com todo o contexto cultural. Seria, portanto, inerentemente polissêmico.

Poderíamos perguntar o que levou Venturi, discípulo do refinado Louis Kahn, a interessar-se pela "cultura de massa". Na verdade, a "descoberta" da cultura de massas acontecia 
Figura 2: Roy Lichtenstein. "Garota afogando-se". Óleo e tinta polimérica sobre tela, $170 \times 170 \mathrm{~cm}, 1963$ naquela época nas mais diversas áreas, quando filmes "B" converteram-se em "Cult Movies", o apego às histórias em quadrinhos transformouse em colecionismo ou cultivou-se com seriedade inaudita a música popular e a ficção científica. Análises acadêmicas desta produção não tardaram em aparecer, sendo as de Venturi pioneiras. Mas esta atitude, que pode ser resumida no termo "pop", já emergira antes nas artes plásticas com a violência de uma explosão.

Imaginemo-nos no começo dos anos 1960, quando as obras usualmente expostas eram derivações do Abstrato-Expressionismo, pontuadas por enigmáticos objetos minimalistas. Grande é o choque do público ao entrar na sofisticada galeria Leon Castelli e encontrar uma imagem banal como "Garota Afogando-se". Inverteu-se a situação da percepção da obra de Venturi. Aqui, impossível seria não reparar na presença estridente das cores chapadas e berrantes ou deixar de pensar sobre o desafio desta pintura, que traz de volta a banida figuração em sua pior versão, o kitsch, contrariando todos os preceitos do alto modernismo. O visitante indaga sobre a razão da presença deste inusitado objet trouvé, reproduzido na escala expandida de uma pintura "americana" , mas exato, polido e com um acabamento industrial.

Hiperdimensionada, a superfície pintada cor-derosa do rosto da heroína revela-se de perto como uma série de círculos vermelhos geometricamente dispostos sobre um fundo branco. Traços negros absurdamente definidos separam superfícies chapadas de cor saturada com a nitidez e o arrojo de uma abstração geométrica. Os "efeitos" gráficos, ingênuos na sua repetição estereotipada - reflexos, brilhos, hachureados -, quando olhados de perto oferecem os prazeres dos detalhes engenhosos de uma pintura abstrata geométrica.

O "tema" da pintura também provoca. Por um lado, é a banalidade escancarada, por outro, percebemos que trata questões humanas eternas e elevadas, o amor e a morte, o papel a que foram relegadas as mulheres na sociedade contemporânea,

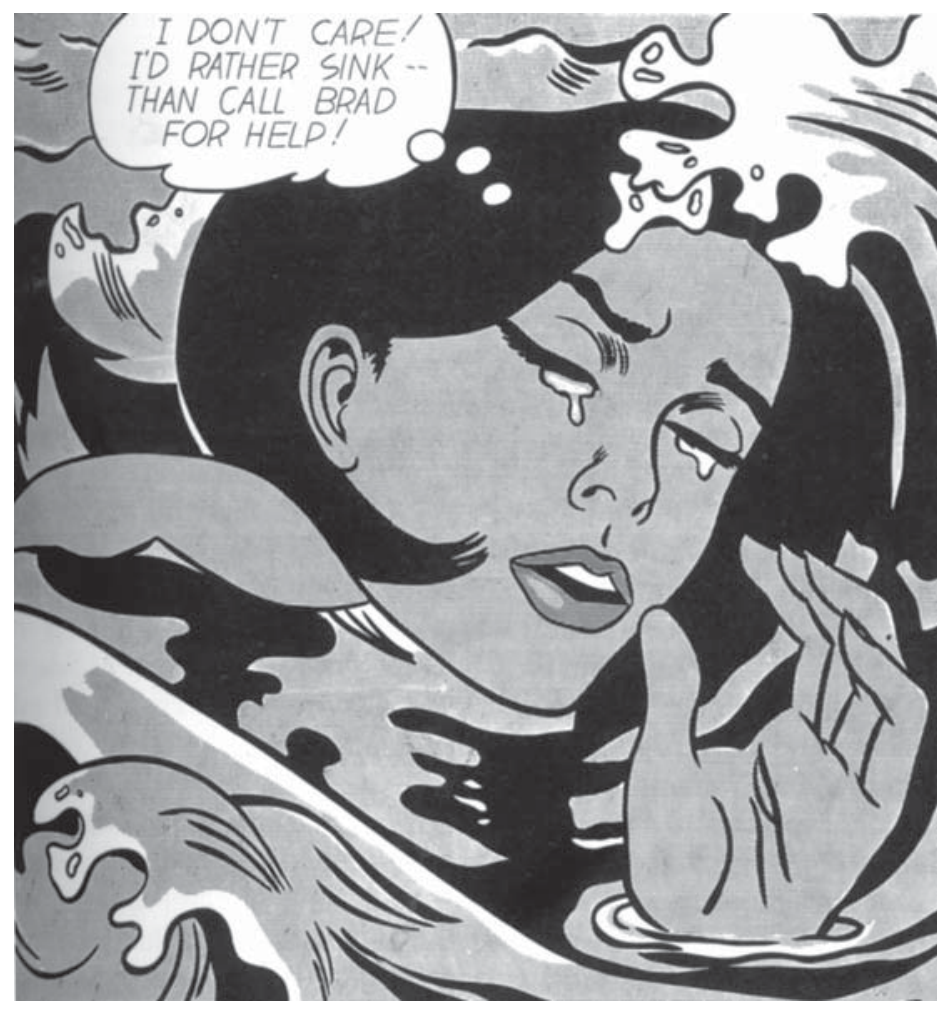


mas tratadas por um meio de difusão cultural tão poderoso como reprodutor de estereótipos. Qual é a intenção do artista: denunciar o comercialismo da indústria cultural ou mostrar a permanência dos mitos humanos eternos em uma nova encarnação? A pintura é opaca a este respeito; a atitude de Roy Lichtenstein é mostrar sem comentar. Nas entrevistas apenas classifica sua pintura como "abstrata" , pois não é uma cópia da natureza. Para o público educado a encontrar nas telas abstrato-expressionistas as profundezas da alma em um máximo de requinte pictórico e originalidade, sobra a perplexidade.

O mesmo "piscar de olhos" de Venturi ao público culto encontra-se no método de Lichtenstein. Um aumento absurdo da escala de uma imagem reproduzida - de centímetros a metros - recria em "arte" a reprodução comercial barata. Redesenhando a precariedade da técnica de impressão, o pintor redime a ingenuidade desta última pela argúcia do olhar informado que a transmuda em engenhosidade.

Paradoxalmente, quanto mais exata a fatura, mais opaca a atitude do artista, maior o estranhamento Figura 3: Roy Lichtenstein. "Escultura de Cerâmica 12", cerâmica, $23 \mathrm{~cm}$ de altura, 1965 causado pela recontextualização da imagem, deixando a razão de ser da pintura em suspenso. Pois o material básico recolhido por Lichtenstein não é o objeto cotidiano com as marcas do uso, ou do tempo, como nas colagens, em que o interesse é a ação humana, nem é um verdadeiro objet trouvé, em que o artista encontra no acaso sua subjetividade refletida. Também lhe falta o sentido transgressor da engenhoca conceptual que é um ready-made. É uma réplica "exata" de uma imagem industrial que não possui original, cópia da cópia. $\mathrm{O}$ artista veicula em seu contexto uma mensagem que já circulava em diversos canais, simulando não modificá-la. Com esta postura ele dissimula não ser um artista, situação expressa na confissão de Andy Warhol: "Queria ser uma máquina".

Fato surpreendente, passados 40 anos, o desenrolar da carreira deste artista pop ainda mantém o interesse. Isto apesar de as operações plásticas empregadas serem diretas, poucas e quase previsíveis. Em "Esculturas de Cerâmica 12", Lichtenstein entregou-se ao desafio de tridimensionalizar fragmentos de História em Quadrinhos. Recriou as xícaras no espaço de maneira tão criteriosamente coerente quanto o procedimento de Theo Van Doesburg ao passar a linguagem das telas de Piet Mondrian ao espaço arquitetônico. Nesta obra, dois produtos industriais, a xícara e a linguagem das histórias em quadrinhos, se encontram tendo a arte como mediação. Mas paira

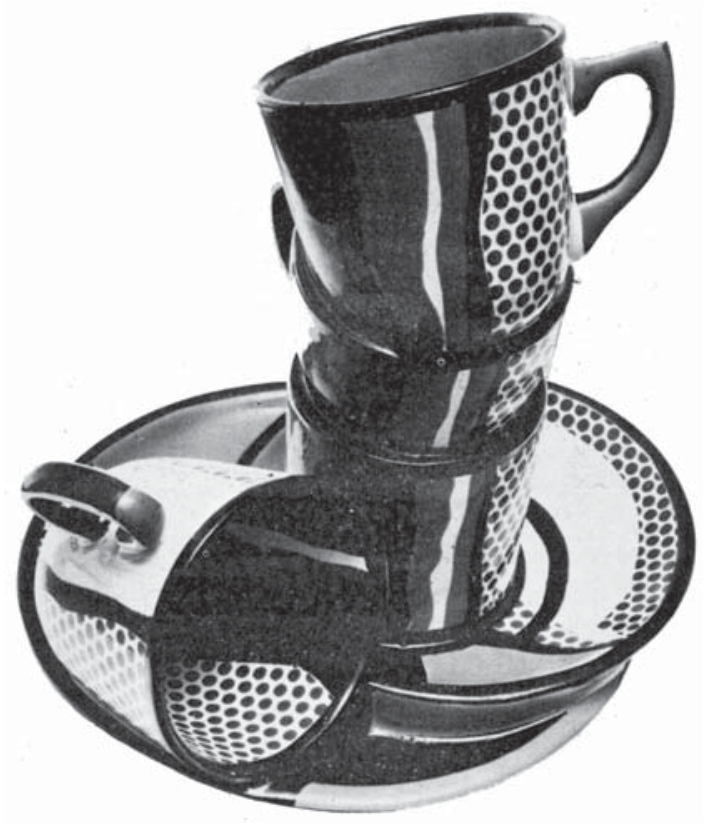


sobre o objeto o espectro esvaziado da "síntese arte-técnica".

Roy Lichtenstein reencenou a descoberta dos expressionistas das potencialidades estéticas da imagem "primitivista", só que de maneira polêmica; a matéria bruta que descobriu estava debaixo de nossos olhos adormecidos todas as manhãs na seção do jornal dos quadrinhos. Ele inaugurou, junto com sua geração, um outro capítulo das descobertas iniciadas pelos românticos, tradição continuada em diversas obras modernas; descobriu o paradoxo de "um vernacular de massa".

Nenhum material, estilo modernista ou imagem contemporânea se mostrou imune à "tradução" lichtensteiniana: Pablo Picasso, Fernand Leger, Expressionistas, anúncios ou a abstração, todas estas imagens foram apropriadas por suas mãos. De onde provém o poder deste método onívoro? A capacidade de apropriação de Lichtenstein lembra tanto a abrangência da informática, disposta a assimilar, traduzindo qualquer informação para dentro do seu repertório, como a idéia de "Museu Imaginário". Existe coerência nesta associação: afinal, as artes gráficas foram precursoras nas comunicações de massas, que almejam abranger tudo e atingir a todos unificando no tempo e espaço o que estava disperso. Nelas, todas as nuanças de cor e tonalidades da tradição cultural ou do existente tiveram de se adaptar ao crivo da nitidez da linha negra. Os três fenômenos, computação, museu imaginário e Lichtenstein, relacionam-se com a questão da assimilação de uma herança por meios de reprodução em massa. A estratégia comum consiste em tornar acessíveis as obras, traduzindo-as ao código específico do meio técnico.

Lichtenstein não apenas copia imagens da cultura de massa, mas mimetiza seus procedimentos ao equalizar com seu toque particular, "anônimo", as especificidades de cada um de seus modelos e convertê-los em "Lichtensteins". Nessa operação, a presença oculta dos procedimentos da técnica vem à tona. O observador reencontra aí explicitamente essas operações de intersemiose, de tradução de um meio para o outro, que percebe quotidianamente à sua volta, e de maneira exacerbada nas comunicações de massa. Sente o prazer de desvelar esta operação tão claramente exposta na obra.
Lichtenstein, porém, torna suas referências em "arte". O preço a pagar por seu método seria a homogeneização, mas a "pasteurização" que efetua em suas obras não as faz cair no banal. Seu trabalho mostra a possibilidade da criação dentro de linguagens altamente formalizadas e estereotipadas por meio de operações inusitadas de descontextualização ou de procedimentos plásticos. Sua obra inteira constitui uma série: revela-se melhor quando cada pintura é lida como um momento deste constante despregar de táticas de apropriação. A opção pela "linguagem estereotipada" obriga-o a fugir da repetição. Assim, o pintor deve reinventar seu método em cada uma de suas obras, mostrar-se não só capaz de criar imagens esteticamente agradáveis mas também que revelam uma situação específica, respeitando as regras do jogo plástico que ele mesmo criou: a réplica dos procedimentos da alta cultura modernista a partir de uma matéria-prima "feia e vulgar". Cada obra deve aproximar pólos opostos, trabalhando na fresta desta oposição.

A atitude irônica que paira na produção de Roy Lichtenstein deve-se a um impulso lúdico, resultado da adaptação de suas obras às pautas dadas pelas imagens que replica. Nelas o artista age como quando no cotidiano concedemos por meio de nossa atuação uma outra interpretação às situações de que somos compelidos a participar. "Arte do fazer", diria Michel de Certeau, arte tática e sutil de aceitação e transgressão da ordem. A diferente recepção americana e européia - uma o acusou de complacente, a outra o percebeu como crítico mostra o desafio que sua postura representou para a sagacidade do público .

Dentro do terreno delimitado pela sensibilidade pop, encontramos em muitas obras de arte um entusiasmo pela multidão de novos objetos que constituem o renovado cenário da vida. Percebemos nela uma nota singular, o auto-reconhecimento de uma geração que teve um "Bildungprozess" inusitado: foi a primeira a crescer sob o impacto da difusão dos meios de comunicação de massa e encontrouse adulta exatamente no auge da expansão econômica dos "gloriosos trinta anos".

Diversas reflexões/criações sobre essa peculiar "educação sentimental" desdobram-se na variada 
produção da Pop Art. Outras obras exalam uma sensação diferente, sem a leveza de toque de Lichtenstein, mas refletindo igualmente a "vivência" moderna, mediada por objetos técnicos e pelas imagens por eles veiculadas. Bem característico desta atitude é o conjunto de serigrafias de Andy Warhol, "Marilyn Monroe", hoje um ícone contemporâneo, imagem que completou todo o ciclo entre a indústria cultural e a alta cultura; recolhida na primeira pela segunda, encontra-se atualmente tanto nos museus como nas camisetas.

Ao manter e mesmo realçar nos silk-screens o sexapeal da imagem inicial - detalhe retirado de um cartaz de filme -, o artista apresenta-se compartindo o mesmo universo cultural do observador leigo. Porém, a repetição absurda e obsessiva da mesma imagem e a imperfeição técnica do silk-screen introduzem um ruído em sua apreciação. Brutalmente, a serigrafia mimetiza nas etapas de sua impressão as camadas do make-up da atriz, mas sem alterar seu fascínio: a estridência das cores exalta a beleza vulgar da atriz, revelando a artificialidade de ambas, do objeto e do signo. Observamos a fatura da serigrafia com o mesmo interesse com que seguiríamos, em uma sessão de maquiagem, a colocação dos cosméticos que realçam a beleza de Marilyn. Camadas que escondem e revelam as feições da mítica atriz. Warhol procura (re)produzir o fascínio mantendo ao mesmo tempo a consciência de estar "contemplando" um estereótipo, fabricado infinitamente.

O procedimento de Warhol de repetir muitas vezes, com alterações mínimas, a mesma imagem, emparelhando-as geometricamente na extensão do campo visual, configura este último como uma malha abstrata (grid). A redundância decorrente de sua repetição é um dado essencial no impacto que causa. A "malha", uma estrutura visual mais do que recorrente na produção do Movimento Moderno, recebe uma profunda guinada em seu sentido usual, "achatada, geométrica e ordenada, antinatural, antimimética e irreal", ao ser identificada com um ícone da produção em massa, a atriz.

Nas mãos de Andy Warhol a "figura simbólica" da "malha" deixa de ser a esperança da síntese harmônica entre arte e técnica, razão e sensibilidade ou, no contexto americano, promessa de abun- dância e satisfação, para revelar-se apenas como o suporte material que veicula o sonho do star system ou do sensacionalismo das notícias sobre tragédias. A " grid" mostra-se análoga às estatísticas de mortes no trânsito ou à redundância standard dos produtos. A forma da malha comparece como a disposição geométrica dos objetos nas prateleiras e vitrines, como o arcabouço da reprodução mecânica e interminável que acaba por sugar a espontaneidade da própria imagem, o meio interposto entre o observador e a vida, que une e separa. A presença da malha na obra torna evidente que o (real) fascínio pela atriz deve sua existência à produção massificada. A arte de Warhol abandonou qualquer teor utópico para tornar-se uma estranha imagem da contemporaneidade; assim, ao recriar o apelo sensual da atriz, simultaneamente veicula uma crítica ao sistema que o possibilitou, condensa uma experiência do cotidiano.

\section{"Indústria cultural" ou "cultura de massa"?}

O Movimento Moderno baseou sua produção em um ideal seletivo, apostando no poder da arte e da arquitetura para promover a sublimação dos impulsos e configurando em seus produtos uma verdadeira proposta pedagógica para as massas. Colocava assim a atitude de sublimação estética e a racionalidade da escolha do consumidor como aliadas, convertendo-as em valor cardeal. O projeto moderno sempre desconfiou da satisfação irrestrita dos desejos prometida pela cultura de massas; o modernismo em geral também desdenhou seus apelos às gratificações imediatas. Porém, desenhava-se dentro do conjunto das obras "pop" uma visão muito diversa, que propunha uma outra relação com a "indústria cultural" ou "cultura de massa".

Esta simples diferença de nomes para o mesmo fenômeno indica quão polêmica era sua avaliação. Na década de 1960, voltava-se a tocar em um nervo exposto, em uma questão central à discussão estética, cultural e política do século XX: qual deveria ser a posição da vanguarda diante da indústria cultural? Tratava-se tão somente da produção desenfreada de kitsch ("indústria cultural") ou abrira-se um novo mundo ("cultura de massa")? É importante lembrar que na origem da arte moderna encontramos sempre a denúncia das vanguardas 
do abastardamento da linguagem promovido pela indústria cultural. Em suas trajetórias, o Movimento Moderno e as outras vanguardas visaram sempre a evitar o rebaixamento da "verdade" inscrita na obra de arte; as experiências vanguardistas eram contrapostas à ilusão promovida pela moda.

Utópico e intervencionista, o Movimento Moderno estruturou-se para harmonizar o que considerava a contradição entre os pólos opostos da alta cultura, o da arte e o da produção cultural industrial. Aceitava a produção em massa, mas desejava reformá-la. No interior do modernismo, as atitudes que pregavam a absoluta autonomia estética foram tão constantes quanto aquelas que desejavam intervir na produção cultural industrial.

O embate entre Walter Benjamin e Theodor W. Adorno sintetiza e explicita as principais atitudes tomadas pela vanguarda perante a indústria cultural.

Figura 4: Andy Warhol. "Marilyn Monroe (díplitico)", serigrafia sobre tela, $208 \times$ $290 \mathrm{~cm}, 1962$
O primeiro encarou o fenômeno como um dado central da atualidade, por mais daninho que fosse para as práticas artísticas e categorias estéticas anteriores, enxergando na nova percepção, "tátil", promovida pelos meios técnicos uma promessa, pois ela poderia abrir possibilidades de intervenção política e cultural. Em sua opinião, a vanguarda não deveria abandonar esta oportunidade a seus inimigos. Com este posicionamento, Benjamin fazia-se porta-voz das vanguardas que pregavam a dissolução da arte na vida.

Foi Adorno quem cunhou o termo "indústria cultural ": "O riso dos espectadores no cinema (...) pode ser tudo, menos bom e revolucionário", foi sua resposta a Benjamin. Criticava a situação atual por identificá-la com uma nova barbárie: "Ambos (a arte modernista e a indústria cultural) carregam as marcas do capitalismo, ambos contêm elementos de mudança. Ambos são pedaços de liberdade que, porém, não se somam".

Adorno desenvolveu uma teoria crítica que, vinculando estética e sociedade, defendia intransi-

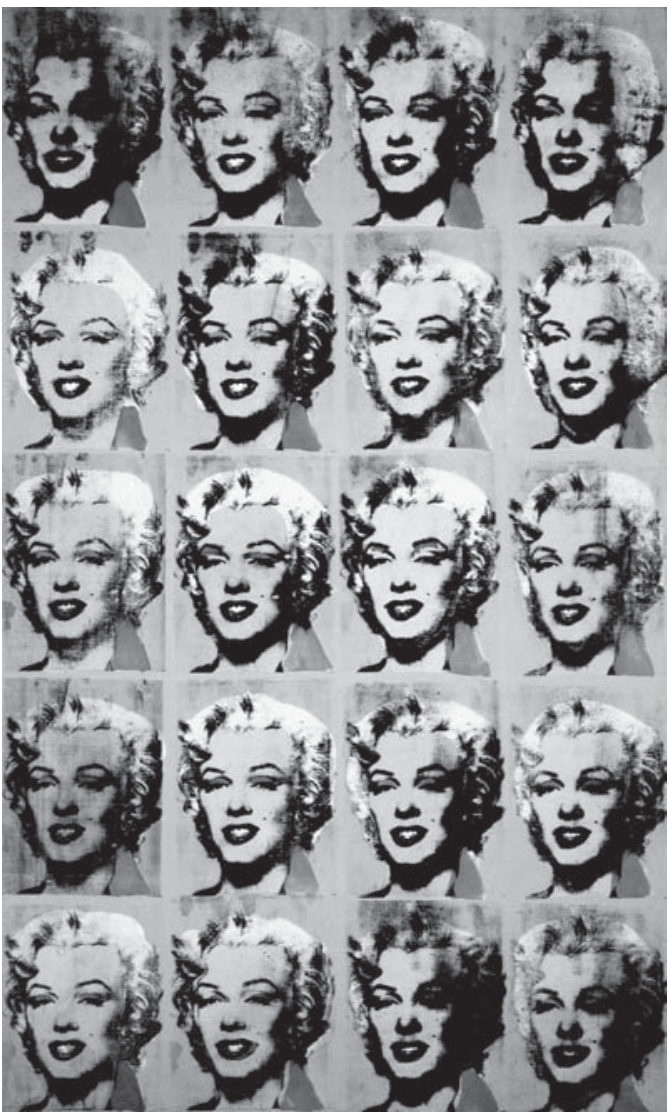


gentemente a autonomia estética desde um ângulo pessimista. A arte, pela situação de autonomia conferida à esfera estética, ainda preservaria, pensava Adorno, a possibilidade de ser recipiente dos resquícios excluídos pela modernização por meio de sua capacidade de "mimese". Defensor da autonomia estética, Adorno pregava o absoluto isolamento da arte como estratégia para defender o que considerava como o último refúgio, refratário à expansão da racionalidade instrumental. Uma vez que acreditava que, nas atuais condições, a verdadeira liberdade humana encontra-se na aparência estética, Adorno privilegiava a absoluta autonomia do objeto artístico; acreditava que, como algo perfeito num mundo imperfeito, por sua simples existência, a arte seria capaz de revelar a inverdade dominante.

Adorno criticara violentamente as teses de Benjamin, desconfiando da capacidade emancipadora do cinema, pois deplorava a situação concreta na qual acontecia a "reprodutibilidade técnica" das obras. Ele reprovava as teses de Benjamin por não trazerem à luz o antagonismo que reside no próprio interior do conceito de técnica, pois pensava que os produtos da indústria cultural, como qualquer produção em série, trariam impressas a racionalidade da técnica e, portanto, a racionalidade do próprio domínio social.

Adorno apontou como traço essencial da arte contemporânea sua "propensão à cor negra". Sua oposição à gratificação imediata dos impulsos se deve à necessidade de renunciar ao fetichismo propagado pela indústria cultural. No encantamento proporcionado pela hipertrofia de um momento da obra, detecta-se a decadência da percepção, fato que une consumidor e indústria, mais interessados no valor de troca da obra do que no de uso: "Os momentos de encanto e de prazer, ao se isolarem, embotam o espírito" . A força de sedução sobreviveria apenas nas obras "onde as forças da renúncia são maiores, ou seja, na dissonância, que nega fé à fraude da harmonia existente".

Seu pensamento tem como pano de fundo a presença crescente da indústria cultural - a exploração comercial sistemática de bens culturais. Ela não seria, de maneira alguma, a "cultura das massas"; estas seriam apenas suas consumidoras, deixaram de ser produtoras. Se, em outros tempos, a arte erudita e a popular se complementavam e se corrigiam, hoje "não é mais possível, a partir da mera soma das duas partes secionadas, formar o todo (...) que só se move em constante contradição ". A indústria cultural está tão intrinsecamente ligada à produção que o lazer que proporciona apenas prepara a volta do trabalhador à sua produção, uma vez que seus produtos são igualmente "a sucessão automática de operações reguladas". Ironiza Adorno o fato de que "só se pode escapar ao processo de trabalho na fábrica e no escritório, adequando-se a ele no ócio".

Como parte da expansão da racionalização instrumental, a indústria cultural "reduz a humanidade em seu conjunto (...) às condições que representam seus interesses". Como o lluminismo, ela revela-se um "engodo de massa", pois liberado da tirania da natureza e da superstição o ser humano vê a "condição de maioridade" distanciar-se na medida em que cai presa do progresso da dominação técnica.

O embate entre Benjamin e Adorno explicitou as posições dos modernistas perante a indústria cultural. Subscrevendo ambas, encontramos as mais diversas posturas. Assim, junto à posição crítica e pessimista de Adorno, encontramos Clement Greenberg e, ao lado de Walter Benjamim, figuras contrastantes como a de Walter Gropius ou Bertolt Brecht.

Quando, a partir das neovanguardas, a relação de antagonismo que o modernismo estabelecera com a indústria cultural foi revista, tanto "apocalípticos" como "integrados" (empregando os termos de Umberto Eco) sentiram necessidade de redefinir os termos deste debate. O novo tom empregado pelos participantes devia-se à onipresença da indústria cultural: esta deixara de ser, como no começo do século, uma experiência esparsa. Nos países do Primeiro Mundo a produção industrial tinha se estendido a todos os segmentos da sociedade, acarretando o fim dos últimos vestígios da produção artesanal e do sistema social do Antigo Regime. Como a posição estratégica que a vanguarda atribuía a si nos anos 1920 ou 30 esvaziara-se na nova conjuntura, agora o artista já não podia mais se imaginar como parte da linha de frente da modernização, literalmente "van- 
guarda" , enfrentando o atraso e a superstição, de acordo com o modelo iluminista.

Agora ele era parte integrante de um sistema cada vez mais hegemônico. A euforia da cena cultural pop, que extrapola o terreno da arquitetura ou o da arte, justifica-se por este contexto em que as artes passaram a ser parte destas mudanças profundas, desempenhando pela primeira vez um papel essencial na produção material. O apagamento das fronteiras entre a indústria cultural e a alta cultura constituiu a experiência profissional de diversos artistas pop e foi vivenciada quotidianamente pelo público. A partir dos anos 1960 aparecera um novo consumo, desenhando uma cena cultural em que a extrema sofisticação técnica dos anúncios os aproximava das obras de arte erudita, agora crescentemente veiculadas por meios industriais. A inovação formal dos produtos industriais deixara de ser parte acessória da produção, dependendo esta última cada vez mais da promoção de um consumo sofisticado.

Nesta nova situação, o elemento estético já não podia ser tão facilmente considerado como o exato oposto das qualidades dos produtos de consumo. Assim, uma Ferrari e um prédio de Alvar Aalto poderiam perfeitamente convergir, por sua alta qualidade, na percepção do público, constituindo cada qual uma "obra-prima" em sua própria categoria. Achatava-se desta forma a oposição tão cuidadosamente definida pela vanguarda do começo do século. A excelência estética perdera sua perspectiva utópica, encaixando-se em um nicho de consumo.

\section{Nova síntese arte-técnica?}

Seguindo este movimento geral e ao contrário da oposição à indústria cultural pregada pelo Movimento Moderno, a neovanguarda optou pela inclusão, misturando os elementos da alta cultura e da mass-media nas suas produções. As neovanguardas assumiram a opção de desordenar o normatizado, adotando a transgressão de toda a tradição recebida, inclusive a modernista.

Na produção arquitetônica a inclusão do "vernacularpop", a aceitação de sua presença como fenômeno fundamental da contemporaneidade, deu lugar, como nas artes plásticas, a uma diversidade de atitudes que ressoa cada vez mais forte hoje em dia. Em "Aprendendo de Las Vegas", Robert Venturi, apresentando uma leitura semiótica da arquitetura e do urbanismo dessa cidade, defendeu-a, paradoxalmente, por sua correção "funcional". Assim, demonstrou como os vulgares anúncios publicitários de beira de estrada, tão desdenhados pelo modernismo, serviam como um perfeito sistema de comunicação no deserto horizontal e aparentemente infinito da "Stripe". Tratava-se de uma solução "quase perfeita", extensível à situação "urbana" criada pela expansão do subúrbio americano. Conseqüentemente pregou a aproximação entre a arquitetura culta e estas soluções, inclusive como maneira de resolver os problemas sociais naquilo que concerne à atuação arquitetônica.

Em seu texto, Las Vegas surge implicitamente como uma metonímia da modernização, de uma outra etapa de modernização. Representaria, nos anos 1970, o papel de objeto paradigmático desempenhado pela indústria nos anos 1920 no imaginário da vanguarda. Comparação inesperada, mas não desprovida de sentido. Las Vegas era resultado do boom de um setor de ponta do desenvolvimento econômico: a indústria do lazer, vitrine da opulência da sociedade. Suas conexões com a fábrica de sonho hollywoodiana eram diretas: os grandes astros ali se apresentavam com a mesma freqüência com que a cidade aparecia como cenário em filmes. Talvez o fato de Las Vegas constituir-se como uma grande cenografia fosse um fenômeno menos superficial do que pareceria à primeira vista. A análise venturiana de Las Vegas como fenômeno de linguagem era coerente com a natureza do objeto.

Este novo ângulo de entendimento da arquitetura, como comunicação de massa, não desejava fundamentar uma proposta utópica como a moderna. Buscava um conhecimento objetivo dos fenômenos tal como se apresentavam no "aqui e agora" da "sociedade afluente". A inclusão de elementos pop como estratégia comunicativa para ordenar o espaço urbano criava uma relação tensa com os ideais Modernos. Venturi pregava uma reversão de atitude na questão da autonomia estética e do funcionalismo da linguagem arquitetônica. Afirmava que a democratização seria trazida pela industrialização, concordando neste ponto com a esperança do Movimento Moderno, mas observava 
que já acontecia mesmo que imperfeita no "aquiagora" americano. Las Vegas não era uma perversão e mereceria uma análise mais simpática. O arquiteto afirmava que o "vernáculo" de Las Vegas, um sistema de comunicação com sua própria racionalidade, oferecia uma alternativa para os arquitetos comprometidos. Dever-se-ia abandonar o anterior idealismo em favor de um pragmatismo eficiente, recortado para as atuais circunstâncias.

Porém, se sua acusação de elitismo lançada contra o Movimento Moderno pode ser sustentada, as atitudes defendidas por Venturi conduziam-no a uma posição moralmente ambígua, de defensor cínico ou ingênuo do comercialismo. Se Venturi ainda ostenta um otimismo moderno quando analisa a eficácia da comunicação de massa, propondo-a como corretivo social, omite-se quanto à análise do caráter da satisfação obtida ou dos desejos despertados. O tom das fotos impressas no livro propõe um tipo de relação diferente do exposto no texto. Elas transmitem uma sensação próxima ao entusiasmo pop pelo "feio e vulgar" das fotos de Robert Rauschenberg sobre o cotidiano dos Estados Unidos. E sua afirmação de que os americanos não necessitam de praças, pois têm a televisão, é tão realista quanto cínica - aceita sem discussão a substituição da vida urbana pela total circulação de imagens.

\section{"This is tomorrow"}

Apesar de tudo, a confiança no papel positivo e decisivo da técnica continuava a ter defensores ferrenhos na linha do Movimento Moderno. Na Inglaterra de meados dos anos 1950, Reyner Banhan defendeu entusiasticamente a incorporação plena das inovações técnicas e da correlata renovação de sensibilidade ao ideário e repertório do Movimento Moderno. O Grupo dos Independentes, reunidos em torno do ICA (Instituto de Arte Contemporânea), juntou por alguns anos os esforços de artistas, arquitetos e teóricos (Banhan, Richard Hamilton, Alison e Peter Smithson, Lawrence Alloway, etc.) justamente em volta do interesse que lhes despertava a "cultura de massas", lembrando que o termo "Arte Pop" foi inventado para designar essa produção e não a artística.

Na enorme diversidade de materiais e temas recolhidos para as exposições "Man, Machine and
Movement" (1955, ICA), "Paralels Art and Life" (1953, ICA, Londres) e "This is Tomorrow" (1956, Whitechapel Gallery, Londres), a preocupação dos organizadores foi captar a especificidade desta "cultura" que só emergira plenamente no pósguerra. Nelas, tanto o conteúdo quanto a própria linguagem redesenharam o cânone moderno de exposições. O público era exposto a um bombardeio indiscriminado de mensagens de fontes contrastantes, confrontando sem mediações essa justaposição. Painéis explicativos modernos conviviam com objetos procedentes diretamente da indústria cultural, soltos no espaço como ameaças à elegância e à ordem. Eram encontros tão inesperados como os que ocorrem em qualquer esquina metropolitana.

"Hamilton, McHale e John Voelcker construíram um modelo de arquitetura de parque de diversões com falsa perspectiva, pavimento liso e luz escura no interior; o exterior, coberto de citações da cultura popular, incluía Marilyn Monroe, uma enorme garrafa de cerveja, um robô recortado de 5,18 m de altura com uma rapariga do filme publicitário relativo a Planeta Proibido. O catálogo incluía uma colagem de Hamilton, 'Que É que Torna os Lares de Hoje tão Diferentes, tão Atraentes?' (...) Assim, a participação do espaço, que tinha preocupado tantos artistas na década de 50, estava intimamente relacionada com a cultura popular, como amostra de um ambiente físico da cidade ou como simulação do ambiente da rua ou de carnaval. "

A reação eufórica do público e da crítica mostrava que algum elemento do cenário cultural, novo e significativo, mas ainda inédito, havia sido captado em tais exposições. Mas como conciliar o desejo por um Cadillac rabo-de-peixe brilhante com a contemplação de uma pintura de Jean Dubuffet? Como valorizar a sobriedade da arquitetura de Mies, estando a berrar ao seu lado o sensacionalismo erótico-mecânico dos cartazes de cinema?

As propostas, embutidas nessas exposições, de "aggiornamento" do ideal moderno ao estado atual da produção industrial e cultural abalaram pontos centrais da formulação original do Movimento Moderno. A inovação tecnológica, antiga aliada dos modernos, foi um dos motores dessas mudanças. Neste sentido, pode-se constatar um crescente descompasso entre a produção arqui- 
tetônica e a de artes plásticas, o que levou à posterior cisão: os integrantes do Grupo dos Independentes nunca harmonizaram suas preocupações em um programa de ação como fizera a vanguarda histórica. A verdadeira explosão de referências que constituíram essas exposições dificultou a possibilidade de sintetizá-las em uma proposta abrangente e conduziu à pluralidade do NeoBrutalismo e da Pop Art.

As propostas arquitetônicas mais arrojadas daquela época lançaram novas dúvidas sobre o projeto moderno, apesar de serem ainda bastante respeitosas com o repertório moderno. As fraturas apareceram sutilmente, tardando em amadurecer. Já podemos discernir a presença de colagens de referências nos projetos da época de James Stirling, como no "Engineering Building " (1959, Leicester), que posteriormente se tornariam claramente "ecléticas" (1980-83, "Staatsgalerie" de Stuttgart), indicando uma quebra na proposição moderna de que toda forma deveria ser necessariamente inovadora por ser a resolução de uma situação específica.

\section{"Plug-in City"}

Apesar do famoso projeto do Grupo Archigram, "Plug-in City", apresentar-se em axonometria, exala dele uma sensibilidade pop, próxima ao filme Yellow Submarine, que volta as costas à elegância e exatidão típicas do projeto neoplástico, introdutor desta forma de representação na arquitetura. Irreverente como convinha nos anos 1960, levantava questões desde sua apresentação, misturando em doses iguais alta cultura vanguardista, ficção científica, história em quadrinhos e novidade técnica, sem deixar de lembrar a "futurologia" de Hermann Kanh.

Apesar de sua estruturação absurdamente tridimensional causar espanto, a "Plug-in City" descende diretamente da "Cidade para 3 Milhões de Habitantes" de Le Corbusier. A fúria analítica da metodologia moderna, a crença na superioridade de Hoje tão Diferentes, Atraentes?" Colagem, $26 x$ $24 \mathrm{~cm}, 1956$.

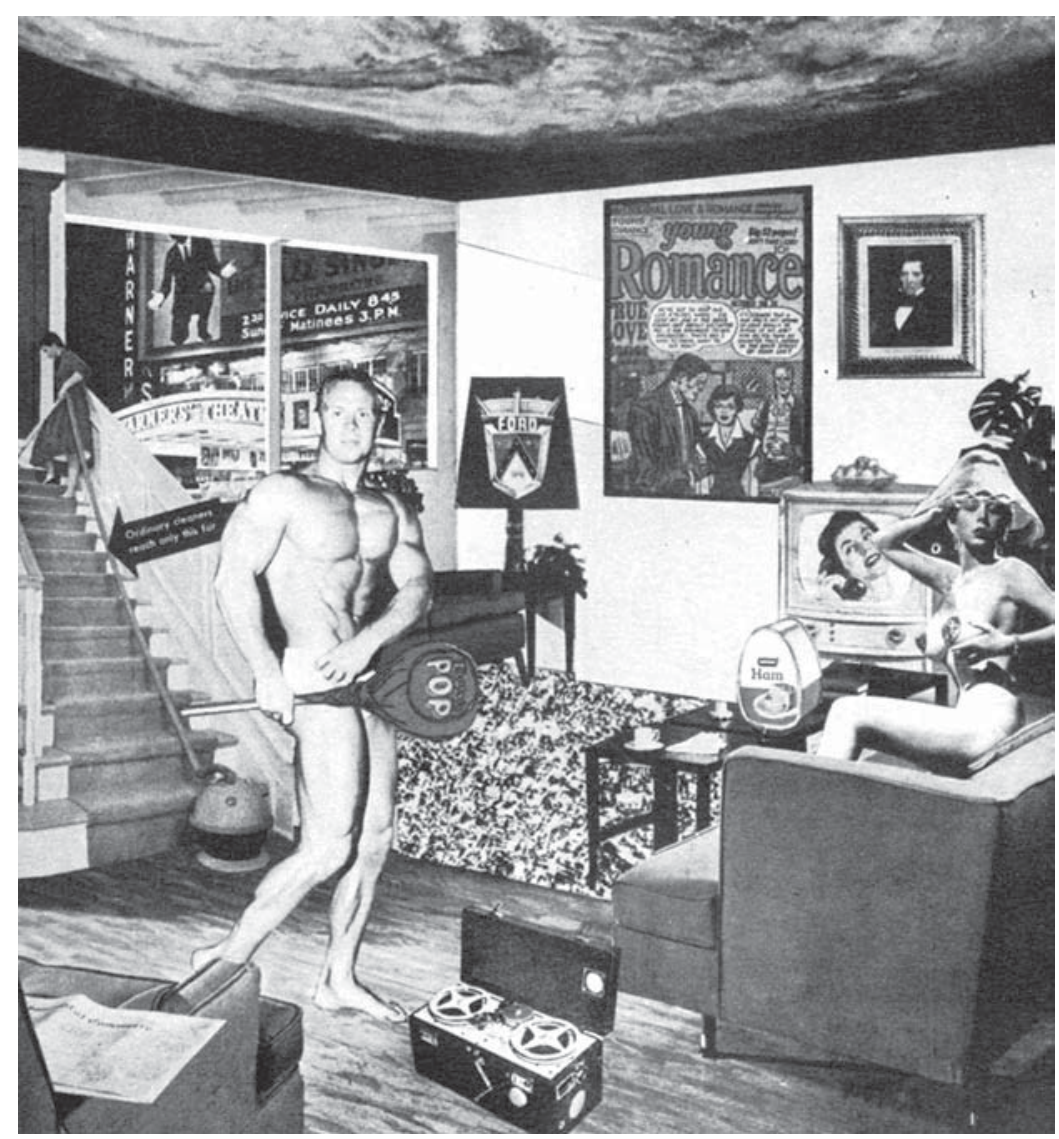


da especialização e separação espacial das funções convergem nessa proposta, apresentada em absoluta clareza visual que se acaba materializando na estetização do espaço. Na "Plug-in City", cada uma das funções indicadas no verdadeiro diagrama bidimensional que é o projeto de Le Corbusier aparece destacada verticalmente das demais, suspensa no espaço e dócil ao olhar, revelando de forma espetacular seu funcionamento. A implantação é alheia, se não hostil, ao solo e ao "lugar": a obra incorpora sem atritos cenários de Flash Gordon à herança dos CIAMs.

A fascinação moderna pelos fluxos de veículos, de pessoas e objetos, eficientemente administrados, metamorfoseia-se radicalmente nesse projeto, que eliminou qualquer traço de estabilidade física ou temporal da cidade. Presenciamos aqui uma estrutura urbana que se caracteriza por sua montagem e remontagem permanentes, em perpétuo processamento. A preocupação pelo fluxo incessante levou à construção de cápsulas pré-fabricadas nômades que podem ser fixadas (plug-in) ou removidas a gigantescos eixos, ao gosto do usuário. Prevendo isso, faziam parte permanente do cenário da "Plug-in City" gigantescos guindastes.

"Plug-in City" é uma ode à modulação e fungibilidade absolutas de objetos e comportamentos. 0 approach construtivista, que louvara a qualidade transitória dos objetos, foi levado ao paroxismo por Archigram. Já que a arquitetura e os objetos da vida contemporânea deveriam ser encarados como instrumentos e não como arte, a atitude mais desejável seria o desprendimento total em relação a eles. Assim, toda a estrutura urbana foi considerada como absolutamente transitória, tornando cada elemento "descartável ", não importando sua escala. Contemporâneos da expansão dos objetos descartáveis no cotidiano e da obsolescência programada do produto industrial, os membros do grupo Archigram elevaram a pasta dental ou o copo de papel ao status de objeto paradigmático. A apologia que Archigram fez destes objetos de consumo contrasta com o idealismo de Le Corbusier. Este último, de certa forma, ainda considerava o produto industrial como um fim em si, ao equalizálo à perfeição das formas puras. Já Archigram "desmaterializou" os objetos ao considerá-los puros instrumentos e portanto impermeáveis à contem- plação. Não sentia qualquer necessidade de "geometrizá-los" para garantir seu status platônico. $\mathrm{Na}$ "Plug-in City", as partes técnicas exibem-se em sua emancipada nudez, orgulhosas de sua disponibilidade combinatória. Juntas e partes acessórias estendem-se pelas fachadas, mimetizando a objetividade de módulos lunares.

Archigram reencontrou o conceito de "Existenz minimum" na caixa de lanches do McDonald's. Como o caráter de slogan de seu nome revela, esta cidade adequar-se-ia à lógica do franchise. Prevendo uma futura "McDonaldização" do mundo, projetaram a total fungibilidade dos espaços e sua futura produção em massa. Na "Plug-in City" todos os hábitos e todos os espaços da existência foram pensados de antemão, assim como cada gesto do freguês ou do atendente fora espacial e temporalmente estudado por aquela cadeia de fast food.

Archigram sacou conclusões extremas de algumas premissas do urbanismo moderno: a absoluta flexibilidade, o total planejamento e industrialização da construção, a estrita divisão espacial das funções e o fluxo desimpedido como a espinha dorsal do projeto. Mas a promessa do "novo homem " moderno esvai-se na vertigem pop-futurista desta proposta ou, então, concretiza-se com demasiada definição. $\mathrm{Na}$ "Plug-in City", a racionalidade da produção invadiria os mais recônditos recantos e sua realização implementaria uma incessante mudança. Mas esta "utopia" de um cotidiano totalmente administrado, negando toda e qualquer imprevisibilidade, seria, na verdade, avessa à verdadeira mudança qualitativa. A possibilidade de um futuro imprevisto assim como da experiência desapareceria por completo neste simulacro. O tom da apresentação desta última utopia moderna revela algo do espírito dos novos tempos. A ausência de teor messiânico na apresentação da proposta desloca-a para o campo do efeito publicitário.

\section{O "Centro Georges Pompidou"}

Deslizamento semelhante dos ideais modernos pode ser vislumbrado no "Centro Georges Pompidou" (1972-77, Richard Rogers e Renzo Piano), projeto considerado como a realização mais próxima das propostas de Archigram. Nele procurou-se incorporar o espírito dos anos 1960, 
lúdico e participativo, a um museu de cultura contemporânea.

Sua estrutura física e espacial é análoga à dos imensos pavilhões criados na última fase de Mies van der Rohe. A simplicidade do volume básico do "Centro", sua estrutura metálica exterior e total flexibilidade espacial do interior vasto remetem ao "Crown Hall " (1952-56, ITT, Chicago). Mas a cuidadosa harmonização entre "arte e técnica" elaborada pelo mestre alemão sofreu uma profunda inflexão no edifício parisiense.

Comparando os exteriores do "Crown Hall" de Mies com os do "Centro Pompidou" percebemos outras sintaxe e semântica associadas à técnica. A inextricável unidade elaborada no primeiro, de reminiscências neoclássicas, rompe-se no projeto de Piano e Rogers, no qual "ossos e peles" separamse em superfícies paralelas como um agitado baixo-

Figura 6: Grupo Archigran Peter Cook. Projeto "Plug-in City", 1964 relevo. Nas fachadas, uma escada rolante envolta em um tubo plástico transparente e toda uma fauna de tubulações industriais coloridas são justapostas às articulações metálicas em uma corajosa exibição das "vísceras técnicas". Este engenhoso "virar do avesso" material e conceptual dos elementos da arquitetura constitui um exemplo único no emprego estético daquelas partes do edifício "que servem" (Kahn). Piano e Rogers conseguiram incluir na linguagem arquitetônica uma matéria-prima até então indigesta. Não se tratava mais de "escondêlas", como fizera Mies, receoso de ferir a pureza geométrica do edifício, mas de extrair significado de sua exposição. Ou seja, a técnica não necessitava mais ser sublimada em forma pura.

O pano de vidro recua, deixando o protagonismo para a estrutura metálica de sustentação. Esta, embora obedeça à proporcionalidade da técnica, volta as costas para a pureza geométrica miesiana e as associações conexas, apresentando-se ao público com um fascinante alarde. No projeto

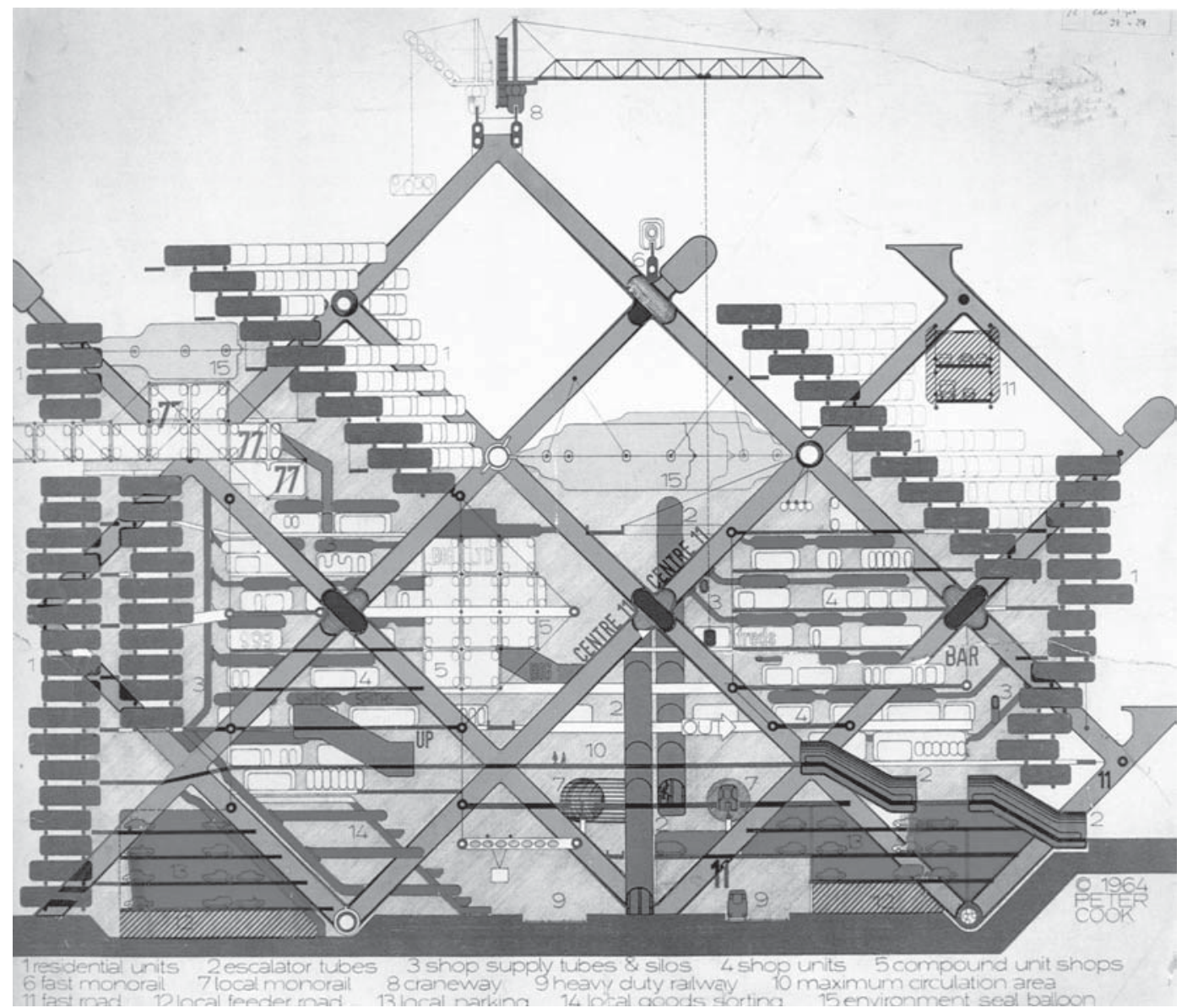


parisiense, os "estilemas" da técnica exibem-se como detalhes significativos em si, desmanchando a cuidadosa tensão entre parte e todo presente no projeto de Mies, e esvaem-se na gratificação imediata. Na selva de acessórios e elementos de sustentação, algumas partes foram pintadas em cores fortes, aquelas codificadas para identificar sua utilização em indústrias químicas.

Da percepção do "Centro Pompidou" derivam inúmeras associações, construídas em torno das imagens "industriais" do navio ou da refinaria. Mas esta mimese da indústria contrasta com aquela moderna que enxergava na máquina a "revelação" das formas puras e de correlatas promessas emancipatórias, como demonstra a entusiástica recepção pública. Nela, a presença da "técnica" foi saudada como uma empolgante experiência sensorial, mas deixando de lado, como desejaria a ortodoxia moderna, seu papel de promotora de comportamentos pautados pelo discernimento. Sua percepção acontece como vibrante experiência "tátil ". A julgar pelo comportamento da massa de visitantes, o "Centro" foi mais identificado com a feira industrial ou com o parque de diversões que com o sonho moderno que o balé harmônico do taylorismo embalava. Como Kenneth Frampton descreveu:

"Uma das ironias não intencionais desta obra parece derivar da vista espetacular da cidade que se desfruta das escadas rolantes envidraçadas pelas quais se tem acesso ao prédio e que estão penduradas na fachada oeste do edifício. Estes acessos são agora quase insuficientes para acomodar os mais de 20.000 visitantes diários, muitos dos quais vão atraídos não pelas atividades culturais mas sim pelo edifício e pela vista."

Neste edifício cada andar abriga um imenso espaço vazio, materialização extrema do ideal de flexibilidade. Mas a posterior necessidade de reformar seu interior indica a sua inadequação prática. O mesmo reparo pode ser feito à conservação da estrutura metálica. A "técnica" é cara, mas funciona como imagem.

As feiras internacionais, tal como a Expo-70 em Osaka, divulgavam há mais de um século uma imagem pública da tecnologia. Nelas, tanto o conteúdo das exposições nos interiores dos pavilhões como o arrojo arquitetônico destes associavam as promessas do futuro às proezas mirabolantes da ciência e tecnologia. Convidadas a passear entre uma arquitetura arrojada e espetacular, inédita em sua modulação, no emprego de materiais altamente artificiais e de configurações inusitadas, as multidões eram apresentadas a produtos que, como os promotores do evento prometiam, logo estariam ao alcance de todos. Não surpreende, pois, que o "Centro Beaubourg" assumisse o caráter de um gigantesco objeto de design a ser vislumbrado com deleite pelo turista após uma peregrinação pelas vielas do Beaubourg.

Na cidade que então começava a se converter em espetáculo a arquitetura funcionou como mais um chamariz para o consumo acelerado de imagens. Redesenhando seu antigo papel de arte pública, ela se articula com as mass-media, ganhando novo alento.

\section{A obra como processo: a arte tecnológica}

Neste processo de estabelecimento de novas relações entre arte culta e indústria cultural aconteceu uma substancial transformação do caráter da obra, que assumiu um forte caráter "processual " em diversas produções. Tanto a natureza do suporte da obra quanto sua percepção sofreram notáveis mudanças, análogas às promovidas pelo desenvolvimento técnico.

Nos anos 1960 reapareceu uma tendência de arte "tecnológica", cuja forte expressão só era comparável àquela dos anos 1920. Assim, as novas tecnologias começaram a ser exploradas nas artes plásticas, em diversos suportes e entendimentos, gerando correntes de forte caráter experimental: Arte Óptica e Arte Cinética, nos gêneros tradicionais artísticos ou em suportes inusitados, como "objetos" ou "ambientes". A Vídeo-Arte e a arte que pesquisava as possibilidades da informática ensaiavam seus primeiros passos.

Em "Prisma", uma instalação de Nicolas Schöffer, o espectador entrava em um ambiente escuro onde eram projetadas seqüências de luzes sobre as formas espelhadas que revestiam as paredes. Como em um gigantesco caleidoscópio recriado em escala ambiental, ele presenciava a aparição 
de seqüências temporais de cores livres ( "luminodinâmicas"), formando inesgotáveis e cambiantes imagens simétricas em um espaço infinito. 0 espectador era imerso em um campo perceptivo total, no qual a recepção das imagens fora desvinculada da presença física de qualquer objeto. Este tipo de instalação de arte cinética propunha uma relação diferenciada com o espectador, exigindo-Ihe uma percepção que não apenas respondesse ao dinamismo visual das imagens, mas incluísse também a presença de seu próprio corpo, já que para ter uma visão abrangente do que estava acontecendo devia movimentar-se no espaço. Assim, ele não só observava como participava do espetáculo.

As escolhas estéticas do Movimento Moderno privilegiaram o sentido da "visão" do observador/ usuário, em detrimento do "corpo", quando definiram os parâmetros da linguagem visual a ser empregada. A sintaxe absolutamente geométrica de De Stijl, por exemplo, associava todos os estímulos sensoriais à visão; redução esta que induzia à associação da percepção visual com a existência de

Figura 7: Richard Rogers e Renzo Piano. "Centro Georges Pompidou", Paris, 1972-77. regras abstratas. O estranhamento causado pela arte ambiental era inevitável.
Outro ponto inusitado para o público educado no modernismo provinha do fato de a imagem ter deixado de ser única e cambiar continuamente no tempo. Esta instabilidade já havia sido inaugurada pela Op Art, cujas pinturas de efeitos estroboscópicos resistiam ao esforço do observador em formatá-las em uma única imagem. Impermeáveis a uma leitura definitiva, exigiam, portanto, uma participação ativa do observador. Como apontou Simón Marchán-Fiz, o centro de interesse deslocou-se: "A obra existe menos como objeto estável do que como geradora de respostas perceptivas, dentro dos limites permitidos pela própria estrutura sintática". Ao público caberia realizar atos sucessivos de resposta ao estímulo. A obra transforma-se em um sistema gerador de transformações que desafia a tendência estruturante da percepção.

O desenrolar das experimentações da Op Art e da arte cinética conduziu à dissolução dos gêneros artísticos. Dos suportes tradicionais passou-se ao objeto e, deste, ao ambiente. O caráter ambiental destas artes redesenhou a experiência visual em polissensorial, incorporando não apenas o tempo e a cinestésia, mas também o som, levando este

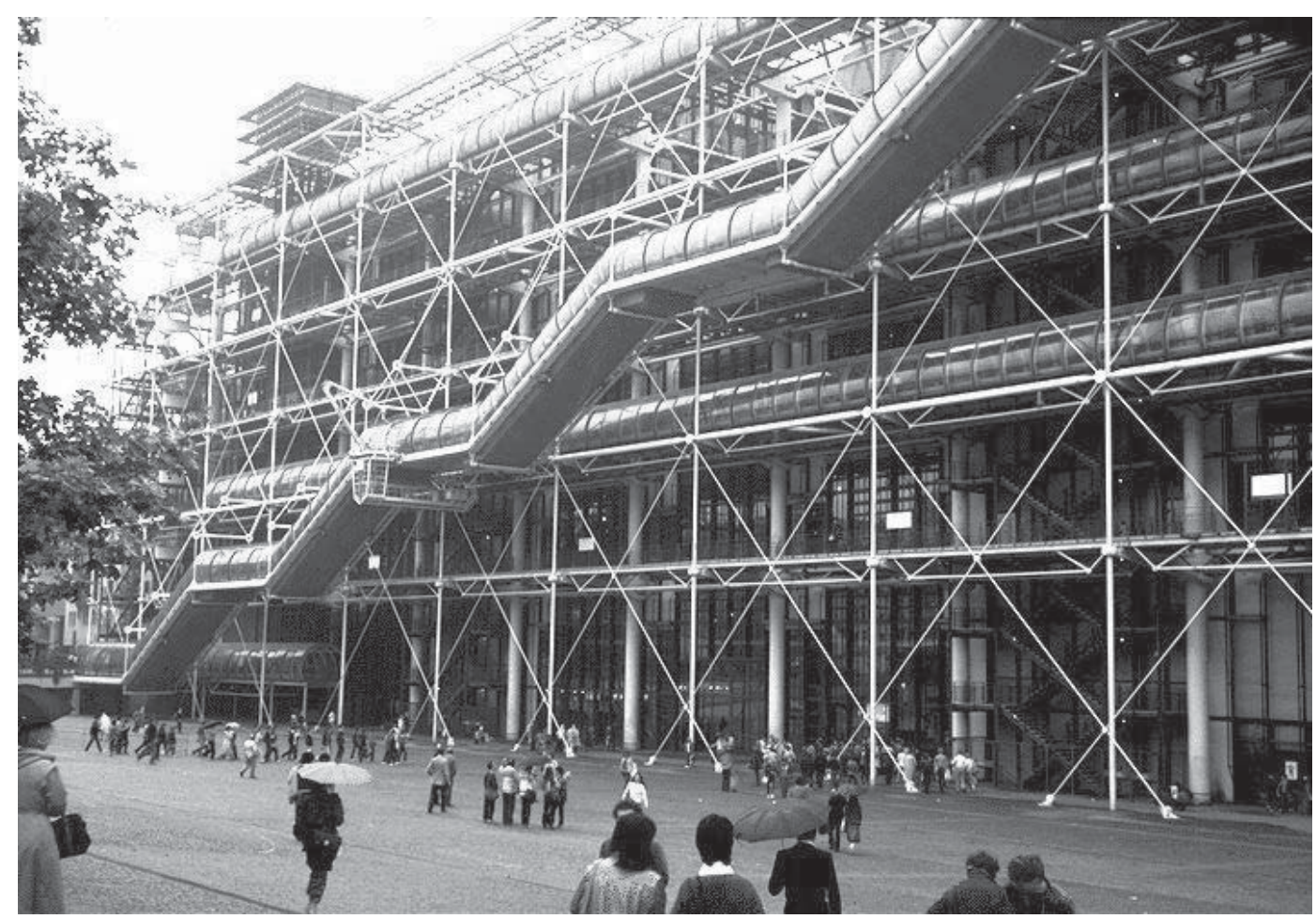


tipo de obra a transformar-se em multimedia. Com tais inovações, a arte cinética iniciou um processo de "desmaterialização" do objeto artístico, ao abandonar a antiga correspondência entre objeto físico e imagem. A virtualidade da imagem e os efeitos cinético e cinestésico colocaram em segundo plano a presença do objeto artístico.

As percepções produzidas na arte cinética acontecem em um tempo e um espaço cujas coordenadas são distintas das do cotidiano ou das da contemplação. A obra "(des)materializa-se" como acontecimento, convertendo-se em uma seqüência temporal que muda objetivamente conforme sua programação.

Desta maneira, a virtualidade e instabilidade da imagem passam para o primeiro plano, a obra converte-se em um processo e sua percepção no desafio de criar associações que dêem conta da abertura da imagem. À sua volta desenrolam-se puras relações de formas no tempo e no espaço. $\mathrm{O}$ que o público encontra à sua frente é um trabalho em que a sua percepção é a matéria-prima. Os efeitos converteram-se no "conteúdo" explícito da obra. Eles remetem a "um conhecimento perceptivo que

Figura 8: Nicolas Schöffer "Prisma". Instalação com projeção elétrica, 1970. à própria percepção". se refere a si mesmo", à "referência da percepção
Todas as associações perceptivas elaboradas em cinqüenta anos de abstração geométrica foram deixadas de lado. A percepção da obra deixava de ser uma experiência de ordem em que claros vínculos associavam a sintaxe a concepções teóricas que extrapolam a pura visualidade; experiência que apresenta analogias com o entusiasmo do público na exploração sensorial da estrutura do Centro Beaubourg.

Outros traços definem as novidades apontadas por estas tendências. Trata-se de uma "ars combinatória" de caráter processual e programado, que trabalha com modulações desenvolvendo, na maioria dos casos, temáticas de ordens regulares. Mas constatase um paradoxo: uma arte de fatura programada, mas que possibilita leituras abertas e promove uma outra atitude do público: uma importante inflexão dentro da arte abstrata, até então próxima das premissas do projeto moderno.

\section{Os novos "sistemas de objetos e sistemas de ações"}

Embora intuída por Baudelaire desde a reconstrução haussmanniana de Paris, o aspecto "transitório, fugidio e contingente" da modernidade evidenciouse de maneira crescente na prosperidade do pósguerra. O consumo acelerado de objetos de

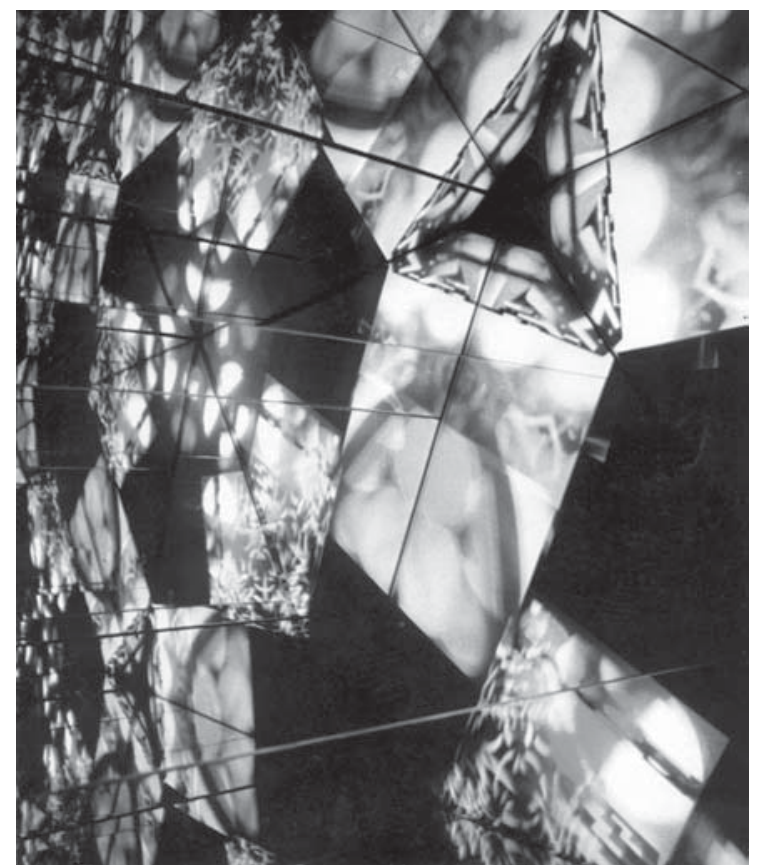


obsolescência programada e o fluxo inflacionado de imagens materializaram este processo de mudanças ao invadir pela primeira vez o cotidiano de amplas camadas da população.

A presença dos objetos perdeu ainda mais de seu antigo poder e significado e sua percepção como metáfora de estabilidade esvaneceu. Os objetos aparecem agora como momentos efêmeros de um processo inexorável, em que "tudo o que é sólido desmancha no ar", convertendo-se em suporte descartável de um fluxo contínuo e acelerado de informações. Mas, detentores de uma carga de informação cada vez maior, os novos objetos técnicos invadiram o cotidiano exigindo novos comportamentos do usuário. Este deveria continuamente aprender a interagir com a constante emergência de objetos técnicos altamente programados, que o induzia a novos comportamentos.

Assim, as diversas ondas de novos "sistemas de objetos e ações" no cotidiano contemporâneo promoveram importantes mudanças na percepção, individual e coletiva. A apreciação da música, por exemplo, diferenciou-se de acordo com a sua presença possibilitada pelo meio técnico, indo desde a indiferença diante da musak no ambiente, a audição autista da fita no walkman, as do rádio do carro misturadas à paisagem ou ao barulho, até a audição em casa, à meia-luz, de CDs programados. Todas profundamente alheias à experiência da música ao vivo. A montagem da imagem e do som no cinema ou nos meios eletrônicos ampliou a percepção não apenas de novas visualidades mas também das temporalidades em que elas se processam. E assim emergiram formas inusitadas de apreensão do tempo a partir da produção de imagens no cinema, no vídeo. Essas seqüências de imagens criam, a partir do movimento, uma nova perspectiva do tempo e aumentam a capacidade humana de relacionar os objetos, deslanchando novas modalidades de pensamento.

O comportamento dos corpos também passa a ser crescentemente moldado pelos aparelhos, que induzem novas posturas, outros tipos e ritmos de atenção. $\mathrm{O}$ usuário obedece às suas diferentes $\mathrm{e}$ absorventes solicitações ao dirigir, andar ouvindo walkman ou ao sentar-se e acionar um computador. Acompanha essas novas posturas a introdução de outras temporalidades em nossas ações. A velocidade de demanda e resposta que pauta o ritmo do novo cotidiano acontece como resposta ao alto grau de informação presente nos objetos. Desde o esforço de programá-los entre si, e programar-se a eles, esses atos importam uma racionalidade nova ao cotidiano.

\section{A "obra aberta"}

As obras de arte dessa época compartem vários traços com esses novos objetos técnicos; ao exigirem o aprendizado de novos comportamentos, pedem mudanças de hábitos análogas às causadas pela introdução dos novos objetos técnicos no cotidiano. Se os atos do cotidiano são crescentemente afetados por uma racionalidade materializada nos objetos que deve ser incorporada pelos usuários, a percepção da arte apresenta um desafio semelhante. A obra converte-se em uma fonte de informações que só ganha sentido quando acionada pela percepção ativa do observador.

Um pouco antes, no Brasil, alguns artistas iniciaram pesquisas que guardavam analogias com os processos que até agora descrevemos. Tendo iniciado suas carreiras como artistas ligados a uma tendência construtiva abstrata, Lygia Clark e Hélio Oiticica logo superaram em suas respectivas obras e de modo intensamente criativo os pressupostos concretistas. Discernimos um projeto semelhante de autocrítica e expansão da área de competência na exemplar trajetória de Lygia Clark. Em sua evolução, ela transformou paulatinamente a concepção do trabalho artístico, culminando na sua "superação".

Uma primeira ruptura aconteceu quando a artista articulou suas esculturas com dobradiças ("Bichos"), alterando assim a relação do observador com a obra. Um "Bicho" não é para ser contemplado (embora não faça má figura como escultura): apenas deixa-se revelar por inteiro por meio de sua manipulação. Dotado de dobradiças que se comportam como uma espinha dorsal, esta construção de placas metálicas triangulares se constitui como um conjunto de possibilidades combinatórias da forma no espaço.

Por meio da manipulação, Clark incorporou à recepção da obra o privilégio antes encerrado no ateliê da exploração plástica entre inúmeras possibilidades. Este "não-objeto" induz o público à 
pesquisa, modificando seu comportamento, uma vez que a informação que ali se encontra só pode ser acionada por meio da interação. A partir dos "Bichos", Lygia Clark abandonou gradualmente o pensamento "construtivo" de suas primeiras obras. Neste processo, o espaço expositivo mostrouse inadequado para suas experiências, o que a conduziu a metamorfoseá-lo em "performance".

O retângulo de tecido que une, atando os pulsos, dois indivíduos, no "Diálogo de mãos", conserva a elegância e economia da forma geométrica abstrata. Mas nessa obra o retângulo comparece apenas como instrumento transparente para possibilitar o toque físico, diálogo tátil entre pessoas. A "arte" metamorfoseou-se em prática educativa dos sentidos, "regredindo" (ou avançando) em direção àqueles antes considerados como mais primitivos, o tato e a cinestesia, e ao suporte artístico mais primordial, o corpo.

O ideal da educação integral do indivíduo redesenhou-se nestes rituais clarkianos. Com isto o projeto " modernista" atingiu um novo patamar, que incluía não só o meio ambiente e a sua percepção visual, mas também a compreensão (e a "descoberta") do próprio corpo. A percepção do próprio corpo converteu-se em um novo tema artístico, inventando um repertório formal e uma problemática inteiramente novos. Esta parte da experiência humana, antes incomunicável por ausência de símbolos, foi mapeada pela incorporação do elemento "tátil", extravasando os limites aceitos da "arte". Assim, Clark expandiu suas fronteiras ao aproximá-las de práticas e temáticas da terapia. O fazer artístico converteu-se em modelo para a integração da personalidade e mesmo para redescobrir perdidos vínculos interpessoais.

Perante a nova configuração do objeto artístico, a experiência do público teve de ser redesenhada, pois esta, desafiando a contemplação, exigia-lhe algum tipo de interação. Os "objetos-comportamento" seguem uma racionalidade que ultrapassa a experiência acumulada do público, mais desnorteando que confirmando suas expectativas. Em suma, torna-se vital para o observador ou usuário adotar novos comportamentos diante da aparição incessante desses "novos objetos" artísticos (e também dos técnicos, como veremos adiante).

\section{Uma outra "pedagogia": a "percepção aberta"}

A atitude a tomar perante esses "novos objetos" tornou-se desde essa época uma grande questão. O público teria de desvendar sua racionalidade e apenas adequar seus atos a eles ou sobraria espaço para ações imprevistas, alheias a um comportamento "programado" ? Boa parte do debate contemporâneo debruçou-se em saber se os "novos objetos" técnicos e artísticos melhorariam as relações entre as pessoas, abrindo novas perspectivas, ou seriam os "objetos técnicos" os verdadeiros "atores" nessas relações.

A neovanguarda desenvolveu-se dentro de uma situação social e cultural na qual o projeto moderno parecia ter sido realizado e que, por isso mesmo, aparecia como co-responsável pelas mazelas existentes (ou, ao menos, como a abdicação da atitude crítica ou experimental na arte). Polemizando com os modernos, ou apenas ignorandoos, a neovanguarda não deu um prosseguimento linear a seu projeto. Foi no cotidiano que contava com a presença crescente da tecnologia e suas novas oportunidades, mas também cada vez mais "programado", que as neovanguardas centraram seus esforços. Foi em resposta a esta situação que, a partir dos anos 1960, se esboçou uma nova "pedagogia" na produção da neovanguarda, que propunha uma outra relação entre a obra e o público, privilegiando a interação e a percepção aberta.

Em "Obra Aberta", cujo primeiro ensaio data de 1958, Umberto Eco explicitou um modelo hipotético (mas também projeto para a produção artística) de relação entre a obra e o receptor: "A obra de arte é uma mensagem fundamentalmente ambígua, uma pluralidade de significados que convivem num só significante", e "tal ambigüidade se torna nas poéticas contemporâneas uma das finalidades explícitas da obra, um valor a realizar de preferência a outros". Interessava-Ihe principalmente o "ponto de vista da relação de consumação (das obras analisadas)".

Eco enxergou um duplo sentido na expressão "abertura" da obra. A abertura de primeiro grau diz respeito à ambigüidade e polissemia inerente a qualquer obra, embora em diversos graus. Mas interessava-Ihe especialmente o ato de sua percep- 
ção: pressupunha que a participação do observador deveria acontecer de maneira não passiva. Ao confrontar um material artístico, na percepção aberta, caberia ao observador "terminar" a obra, concedendo-lhe um sentido particular sempre passível de recriação. A abertura de segundo grau refere-se à instabilidade e desaparição do tema ou leituras únicos na própria organização formal da obra. Eco defendia ser este campo de experimentação parte essencial da produção contemporânea, na qual a obra assume cada vez mais o caráter de uma proposição aberta feita por seu autor, que só se finalizaria quando executada, cada execução convertendo-se em evento único. A interpretação do executante (e a do público) deveria ser entendida como parte essencial do processo de elaboração e mesmo de criação e não apenas como simples "execução" da obra. Finalmente, na opinião de Umberto Eco a "Obra Aberta" constituiria uma verdadeira "metáfora epistemológica" e teria uma função: "Em um mundo em que a descontinuidade dos fenômenos pôs em crise a possibilidade de uma imagem unitária e definitiva, esta sugere um modo de ver aquilo que se vive, e vendo-o aceitá-lo, integrálo em nossa sensibilidade".

Figura 9: Lygia Clark e Hélio Oiticica. "Diálogo de mãos", fotografia, 1966
Nas relações com o público estabelecidas pelas neovanguardas, de especial importância foi a tomada de consciência da necessidade de transferir o campo de batalha para o interior dos signos e deixar de considerá-los transparentes, tirando o observador de uma atitude contemplativa passiva. Da nova relação entre a arte e o público deveria resultar a formação de uma atitude crítica e distanciada deste último, capaz de interagir com as novas oportunidades, mas sem abdicar de sua iniciativa. A nova arte pressupunha tanto uma vontade de experiência por parte do observador como sua consciência da dificuldade e precariedade do conhecimento na atual situação de instabilidade.

Eco apontou como outro traço da obra aberta a tendência da produção contemporânea à "processualidade". Podemos pensar que, de certa forma, a processualidade é uma decorrência lógica da recepção aberta na produção da obra. Na perene ação da modernidade sobre a arte, a emergência da processualidade é um sintoma de que a tarefa crítica do modernismo sobre a tradição artística chegara ao fim. A obra de arte tradicional compartia com o monumento o sentido de permanência. Encarada como guardiã contra o tempo, ela concentrava em si qualidades de estabilidade, em sua integridade e autonomia. Agora, configurada como processualidade, a obra encaixa-se plenamente nos fluxos e metamorfoses da modernidade. Quando o objeto

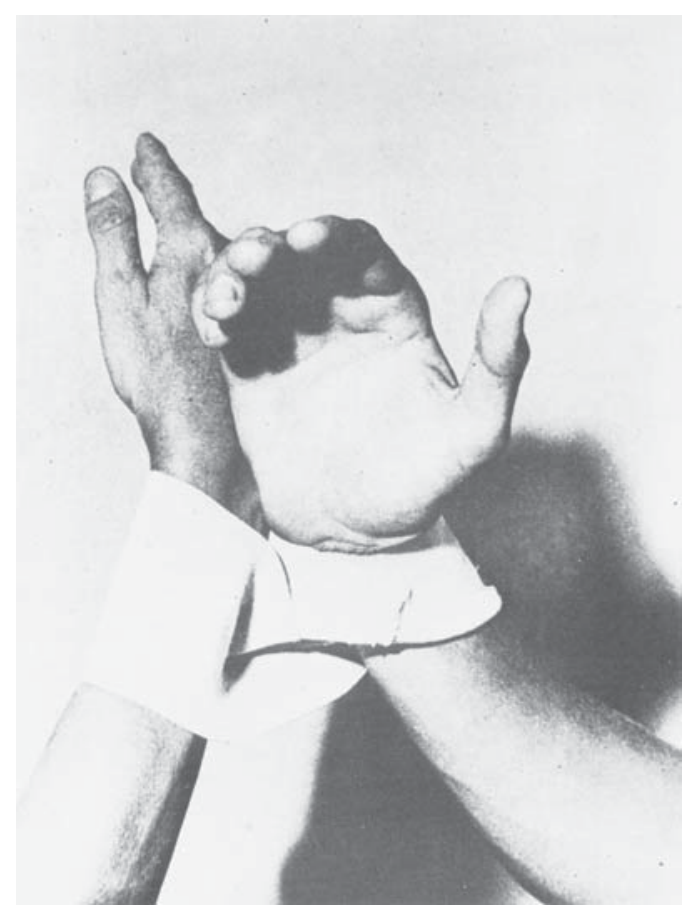


de arte metamorfoseou-se em evento não foi apenas a percepção espacial que cedeu importância à temporal, mas também caíram simultaneamente as diferenças entre os gêneros artísticos e a barreira entre arte e cotidiano.

Para perceber a novidade da processualidade neovanguardista em relação à produção da vanguarda negativa, devemos pensá-la em conjunto com os novos desenvolvimentos técnicos. Nesta nova forma de montagem, processual, a autonomia da arte não é negada em abstrato, como no Dadá, mas em favor de uma "intertextualidade" tornada cada vez mais concreta em razão de mudanças técnicas, econômicas e sociais. Se observarmos os desenvolvimentos contemporâneos em outras áreas, constataremos a formação de uma grande rede cruzada de referências.

\section{Novos paradigmas no desenho industrial}

A partir dos anos 1970, a presença de novos fatores como a eletrônica e o contemporâneo aumento do fluxo de informação levaram tanto a mudanças na produção material como a estabelecer uma nova relação com o público, educando-o para o exercício de novas formas de percepção. Como conseqüência, a crença na validade universal da "percepção programada", e mesmo na máxima de que "a forma segue a função", deslocou-se para um segundo plano no campo do design. Isto conduziu a uma situação paradoxal, pois, se por um lado a neovanguarda pretendia induzir em seu público uma "percepção aberta", a produção industrializada também irá lançar mão dela simultaneamente.

Podemos resumir em outro slogan a "desmaterialização" (dos objetos e das ações), os fatores que referendaram este abandono de paradigmas modernos. O fenômeno da "desmaterialização" apresenta duas faces vinculadas. Por um lado referese à miniaturização física dos objetos técnicos e, mais exatamente, à opacidade do funcionamento dos aparelhos eletrônicos e informatizados. Mas também as próprias ações humanas se desmaterializam, pois o trabalho deixou de acontecer principalmente sobre a matéria, para assumir maior importância a elaboração da informação. Conseqüentemente, muitas vezes o modelo lingüístico substitui o modelo funcionalista no projeto - já que os aparelhos de última geração executam operações sobre informações e não somente ações físicas como as máquinas. Este foi, em síntese, o câmbio paradigmático.

Abrindo e examinando qualquer aparelho eletrônico nos deparamos com os limites do paradigma (mecânico) moderno. Constatamos a impossibilidade de visualizar a função desempenhada pelas partes do aparelho. Diferentemente da ação da energia mecânica, não podemos perceber ali a presença da eletricidade. A transparência visual das funções, crença surgida na época da hegemonia da energia mecânica, entra em curto-circuito diante da opacidade das válvulas, dos transistores ou da miniaturização dos chips. A superfície, carapaça, tela ou teclado de um aparelho eletrônico servem de mediação entre as suas operações e o desempenho humano. A imagem eletrônica que percebemos não está "fisicamente" presente e o que está é tão diminuto e complicado que se tornou inescrutável para o observador leigo. Este fato coloca uma necessidade: não mais de organizar a visibilidade do funcionamento dos mecanismos, mas de projetar carapaças ou extensões que lhe concedam uma presença ou visibilidade que permitam o manejo de objetos miniaturizados. Em um produto como a câmara fotográfica de funcionamento automático, a ergonomia passou a ter mais importância que a visualização. O walkman exemplifica esta nova tendência: em seu projeto, a importância anteriormente atribuída ao aspecto visual reduziu-se em favor da adequação do objeto ao corpo e à manipulação. O objeto desmaterializa-se, virando extensão táctil do corpo. Nele, design e moda combinam seus esforços, uma vez que seu porte define um estilo de vida.

Concentrou-se uma carga tão alta de informação nesses microobjetos que seu usuário passou a necessitar de uma complexa mediação. Parte importante do design do computador transferese ao projeto da apresentação visual de suas operações, de forma a torná-las rapidamente compreensíveis ao usuário. O design converte-se no projeto das superfícies de uso. Como a tela de cristal líquido acopla-se cada vez mais aos mais diversos aparelhos, o monitor converte-se pouco a pouco na interface mais importante entre o homem e o aparelho. 
Nos anos 1970, tornara-se evidente que os objetos e ambientes, mesmo os cotidianos, tendiam a se constituir em partes de um sistema crescentemente planejado. A energia elétrica conectava em uma só rede objetos e ações humanas, antes isolados, constituindo-os em um sistema. Analogamente ao efeito de um conceito, que é capaz de criar identidade entre coisas distintas, esta rede elétrica equalizava atos como iluminar, limpar, aquecer ou cozinhar, todos resultando do toque de um botão. Atos com começo, meio, fim e com finalidades tão distintas e que demandavam uma atitude mental e corporal específica foram "abstraídos". Um processo análogo atingiu os móveis, cuja produção modulada converteu cada peça do mobiliário em unidade intercambiável de um sistema, resultando no enfraquecimento da relação que unia cada móvel à especificidade de cada ato humano. Como resultado, surgiu a estratégia da "ambientação", capaz de compor interiores pela combinação das qualidades abstratas dos objetos. Assim, todos os itens passam a ser intercambiáveis, relacionando-se entre si em um grande sistema.

Novas gerações de aparelhos se sucediam (rádio, telefone, vitrola, rádio portátil, TV, CD, vídeo, TV a cabo, fax, internet), permeando o lar com o fluxo contínuo e crescente de informações do exterior, no mesmo ritmo em que o isolava do entorno imediato, fenômeno que foi acompanhado pela capacidade de inter-relação entre os aparelhos; tanto que hoje já se prevê sua combinação em uma única rede. Sendo esta rede conectada ao mundo exterior, gera-se uma mudança no caráter deste "espaço privado". Assim, a relação entre interior e exterior, espaço público e privado, ganha outra qualidade. A localização espacial das atividades de trabalho e lazer muda, assim como sua temporalidade, na exata medida em que a comunicação torna-se cada vez mais móvel, nômade, sem perda de sua eficiência ao conectar-se com as redes. Indivíduo e "mundo" (as redes de comunicação) estão intimamente conectados, mas o resultado paradoxal foi o isolamento do primeiro em relação ao meio ambiente imediato. As comunicações intersubjetivas crescentemente mediadas pelos objetos levaram Jean Baudrillard a afirmar que é a relação estabelecida por meio dos objetos, mais que com outras pessoas, que integra o indivíduo na ordem social. Uma nova ordem se desenha, mais complexa. Como o walkman, surgem cada vez mais produtos desenhados para o indivíduo na multidão, mas que tem o efeito de isolá-lo do entorno imediato, conectando-o com imagens distantes. De certa forma, estes produtos convergem com as análises de Robert Venturi que priorizaram em sua interpretação da cidade americana a absoluta circulação de imagens em detrimento do "lugar" ou do "estar".

A ação humana sobre a matéria cede lugar à elaboração de informações, pois, de certa maneira, a ação humana "desmaterializou-se". A funcionalidade técnica de um objeto deixou de ser medida apenas por sua eficácia em dominar a natureza, importando mais a relação que estabelece com os objetos do sistema em que se insere. Neste momento histórico, o principal trabalho deixa de ser a operação sobre a matéria bruta, passando a ser a transformação de signos ou a influência no comportamento das pessoas.

Outro aspecto, aguçado pela informática, foi a dependência dos objetos do fluxo de informação que permeia toda a sociedade. Os designers constataram que a percepção do produto pelo usuário é semeada por cadeias de associações que o vinculam com representações provenientes das mais diversas esferas da vida. Tomou-se então consciência destas linguagens, entendendo-se os ambientes e objetos como um campo de trocas simbólicas e lugar de batalhas de significado. 0 cotidiano passou a ser encarado como um jogo e confronto de representações, nas quais tanto manipulações, simulações, afirmações como atitudes objetivas constituem planos interpenetrantes. Em decorrência disso, as novas propostas de design preferiam encarar o objeto como o suporte de uma vasta gama de mensagens. Como Lucrécia Ferrara definiu, "o significado de um produto representa o conjunto de contextos em que este está presente".

Segundo a autora, o desenho industrial reconheceu o papel comunicativo dos objetos, deixando de encará-los como ferramentas "transparentes" em sua objetividade, sem espessura semântica, passando a ser papel do desenho industrial indicar possibilidades para o comportamento do usuário: "A função do produto nos nossos dias é sua capacidade de informar sobre tecnologias, materiais, outro modo de viver, outros comportamentos, outra ideologia". O desenho deixou de ser apenas o projeto 
do produto isolado, para converter-se em "desenho ambiental, no qual o produto e suas qualidades contracenam com o usuário e sua capacidade de processar informação". Assim, a semântica de um produto industrial pode se originar e se expressar em diferentes linguagens. "A linguagem para gerar informação depende da capacidade perceptiva do receptor em que, por similaridade, associa índices imprevistos que nada parecem dizer".

O conjunto de novas atitudes no design indica a adoção por parte deste de posicionamentos próximos aos desenvolvidos na arte a partir dos anos 1960, que propunham uma "percepção possível" ou "aberta", na qual "o intérprete promove atos de liberdade sobre a obra" e onde, "a produção da obra supõe recepção".

\section{A função da ficção}

Mas permanece uma questão: embora possamos afirmar que os paradigmas recentes do design compartem com a obra de Lygia Clark ou a de Hélio Oiticica a fé na potencialidade da " percepção aberta", assim como enfatizam a "desmaterialização" da obra de arte ou do objeto técnico, devemos nuançar esta convergência. O horizonte que vislumbram não é o mesmo: é importante perceber que, nesta comparação, permanece uma diferença intransponível entre o horizonte emancipatório presente nas propostas feitas por estes artistas nas décadas de 1960 e 1970, tingido de tonalidades utópicas, e o atual ambiente político e cultural em que se materializam os novos paradigmas do design, caracterizado antes de tudo pelo pragmatismo. Em tal ambiente, em que o que importa é cada indivíduo saber escolher o "estilo de vida" adequado, a "obra aberta" pode facilmente acabar facilitando o consumo cultural. O que foi criado como antídoto contra uma situação teorizada como "sociedade do espetáculo " pode sem dificuldade ser absorvido por esta última.

Nos anos 1980 ficaram claros os vínculos entre os ideais do Movimento Moderno e a especificidade de um tipo de produção, o fordismo. Este promovera a estandardização da produção, preferência compartida pelo Movimento Moderno. Tal modo de Schneider Brakel). "Que tipo de maçaneta é você?", 1991. Anúncio. organização da produção tornava desejável a criação de um público consumidor com necessidades igualmente estandardizadas. Havendo a possibilidade do

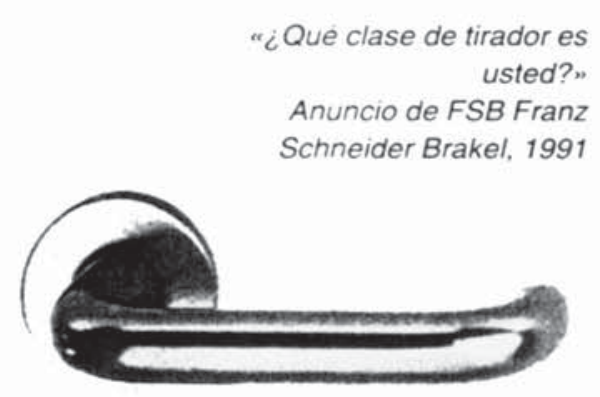

Diseño anonimo. Tipo: ejecutivo/a presuntuoso/a

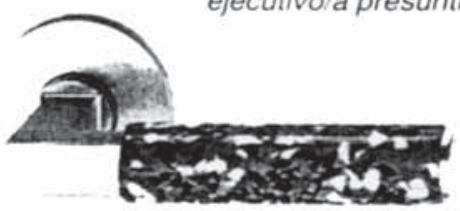

Diseño A. Mendini. Tipo: Trepador/a que desea hacer carrera

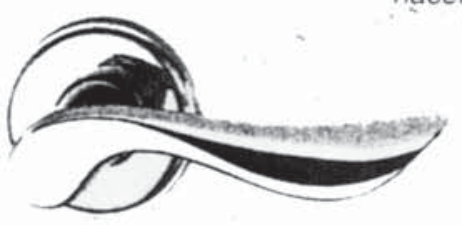

Diseño J. Potente. Tipo: Hombre mujer de negocios con exito

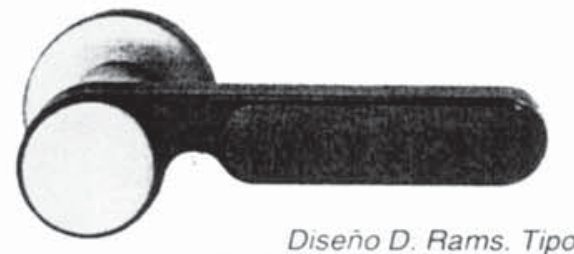
Profesional liberal intelectual

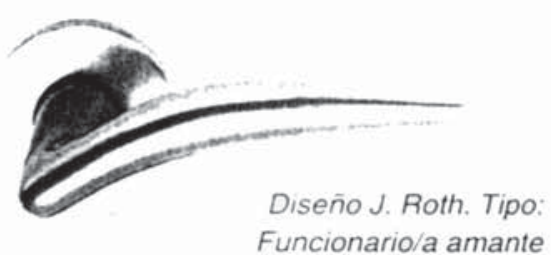
del orden

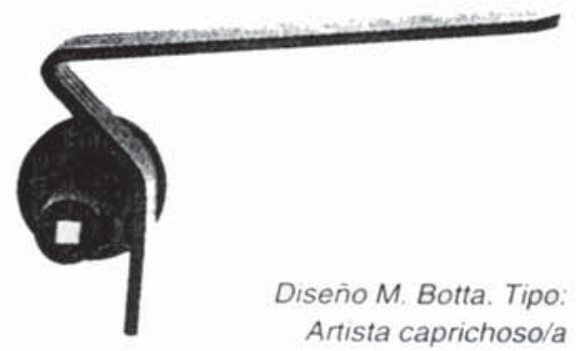


crescimento constante do emprego industrial e do consumo, imaginou-se que estas se converteriam no padrão social hegemônico.

A mudança de paradigma econômico que sucedeu o desenvolvimento acelerado dos "gloriosos trinta anos" deu lugar à emergência de formas de produção, baseadas na mobilidade do capital financeiro e que enfraqueceram a própria idéia de planejamento e os ideais modernos a ele associados. O toyotismo, maduro na década de 1980 com o sistema "just in time", permitiu um grande aumento na flexibilidade da produção, agora disseminada e terceirizada. A ênfase deslocou-se da produção para a comunicação, possibilitada pela informatização, economizando-se em estoque, em espaço e em tempo. Tornava-se possível gerar produtos sob encomenda, cujo desenho moldava-se mais ao perfil específico de cada consumidor ou às necessidades de faixas de consumo diferenciadas. Não apenas aparece em número crescente uma maior diversidade de produtos e de serviços, mas também aumenta a relação entre o aspecto comunicativo dos objetos e o marketing. À produção dos objetos corresponde a criação e disseminação de um sem número de imagens vinculadas a eles. Hoje, o "produto standard", elogiado por Le Corbusier, tornou-se uma entre muitas das opções dentro do mercado estruturado em fluxos de informação.

A atitude do Movimento Moderno diante do fenômeno da moda sempre foi de desconfiança, quando não de hostilidade. Era-Ihe estranha a dialética identificação e diferenciação da moda, já presente nos tempos de Georg Simmel. Sua resposta foi padronizar e depurar as qualidades essenciais do objeto, a famosa síntese entre "arte e indústria" . Hoje, porém, o antigo homem universal, representação compartida pelo fordismo e pelo Movimento Moderno, deu lugar ao consumidor que se define por meio dos produtos que consome, construindo a partir deles seu "estilo de vida". Em sua abordagem de Las Vegas, Venturi demonstrou como a imagem da "técnica" elaborada pelo Movimento Moderno deixou de regular as relações entre os indivíduos e como o forte vínculo proposto pelo projeto moderno entre ética e estética foi ofuscado pela luz multicolorida emanada pelo néon da Main Street.

\section{Referências bibliográficas}

ADORNO, T. W. Teoria estética. Lisboa: Edições 70, 1993.

ADORNO, T. W.; BENJAMIN, W. Textos escolhidos. São Paulo: Ed. Abril, 1980.

ALLOWAY, L. American pop art. Nova York: Macmillan Publishing Co. Inc., 1974.

AMARAL, A. (Org.). Projeto construtivo brasileiro na arte (1950-1962). Rio de Janeiro: MAM; São Paulo: Pinacoteca do Estado, 1977.

ARANTES, O. G. R. O lugar da arquitetura depois dos modernos. 2. ed. São Paulo: EDUSP, 1995.

BAUDRILLARD, J. Sistema dos objetos. São Paulo: Perspectiva S.A., 1973.

BÜRDEK, B. E. Diseño, historia, teoría y práctica del diseño industrial: Barcelona. Editorial Gustavo Gilli, 1994.

ECO, U. Obra aberta. São Paulo: Ed. Perspectiva, 1988.

FERRARA, L. O olhar periférico. São Paulo, Edusp/ Fapesp, 1993.

FRAMPTON, K. Historia crítica de la arquitectura moderna. Barcelona: Ed. Gustavo Gili, 1993.

JAMESON, F. Pós-modernismo. A lógica cultural do capitalismo tardio. São Paulo: Ática, 1997.

JAMESON, F. As sementes do tempo. São Paulo: Ática, 1997.

LIPPARD, L. R. A arte pop. São Paulo: Verbo/EDUSP, 1976.

MARCHAN, S. Del arte objetual al arte de concepto. 1960-1967. Epílogo sobre la sensibilidad "postmoderna". Madrid: Akal, 1997.

SANTOS, M. A natureza do espaço: técnica e tempo, razão e emoção. São Paulo: Hucitec, 1997.

VENTURI, R.; SCOTT BROWN, D. Aprendiendo de Las Vegas. El simbolismo olvidado de la forma arquitectónica. Barcelona: Gustavo Gili, 1978. 


\title{
Da função à ficção
}

\section{Fabio Lopes de Souza Santos}

\begin{abstract}
The article aims to discern, within the cultural production of the 60 's, background convergences among attitudes in areas such as design, architecture and fine arts, examining the "production" of Roy Lichenstein, Andy Warhol, Robert Venturi and Lygia Clark, design and Umberto Eco's "opera aperta" concept, from the point of view of the qualitative change of the perception, defined as "open". Far from being a minor question, the change in the public's and user's role, embedded within the above-cited productions, questioned central tenets of modernism, and especially, the relationship between the modern movement and the cultural industry.
\end{abstract}

Key words: art, architecture, modernism. 